\title{
Hitler, Britain and the Hoßbach Memorandum
}

The Hoßbach Memorandum is the most famous and most controversial document in the history of the Third Reich. Yet there is no critical edition of it - a telling example of the degree to which historians of the twentieth century are swamped by their sources. Every line of the document deserves close study. It contains one of the classic statements of Hitler's racial philosophy and of the policy of the conquest of living space to solve Germany's economic problems. On this level it is comparable to passages in Mein Kampf and the Memorandum on the tasks of the Four Year Plan. But the Hoßbach Memorandum also offers an insight into another dimension of Hitler's thought: the first recorded detailed argument about when and how the conquest of living space was to begin. The essence of this argument is that Germany had limited time at its disposal because its relative strength compared to its opponents would decline after 1943-45 and that was therefore the final date for action. Hitler appeared confident about the international situation. The weakness of the British Empire, which he elaborated in some detail, and the domestic divisions of the French Republic, Russian fear of Japan and Polish fear of Russia, the favourable attitude of Italy so long as the Duce was alive, all he declared offered Germany an opportunity to destroy Czechoslovakia and simultaneously to absorb Austria with little risk of intervention by other powers. Hitler also discussed two possible developments which would enable Germany to act before 1943-45: a domestic crisis in France which made it unable to go to war, or France becoming involved in war with another power which he saw as an immediate possibility for 1938 arising out of the Spanish civil war. Hitler pointed out that the details of these particular conjectures were subject to change. But the decisive features of his argument would not be affected: they were that Germany had limited time to exploit its relative strength and that the existing international situation was favourable for destroying Czechoslovakia without setting off a general war. In short, Germany had to expand during the next six to eight years to solve its problem of living space and, while all expansion involved some risk, an opportunity of, in Hitler's terms, maximum gain with least risk lay within its grasp.

The importance of the Hoßbach memorandum has been questioned by historians on various grounds. Doubts have been raised, in the first place, about the authenticity of the text. Others have questioned whether Hitler's remarks should be taken literally. The purpose for which the meeting on 5 November 1937 was called, namely to discuss the failure of the rearmament programme to meet its targets, and the associated disputes between Blomberg and Göring, led Mr A. J. P. Taylor to suggest that Hitler was simply ranting to evade having to decide between his powerful subordinates. This was a version of an argument first put forward by Göring in his defence at the Nuremberg tribunal, namely that Hitler's statement had been designed to frighten the generals into a faster pace of rearmament by confronting them with the possibility of military action in the near future ${ }^{1}$. Questions have also been raised about what Hitler said, whether it is consistent with his other statements and whether some parts of his argument are not so implausible that they can only have been included for rhetorical effect not because he meant them seriously ${ }^{2}$. Conversely, the Hoßbach Memorandum has also been seen to provide important clues to other pressures propelling Hitler towards aggression: concern about domestic politics, particularly economic problems and the effect on living standards, and concern about his health and age and that of the party ${ }^{3}$. 
It cannot be the purpose of this article to review all the questions raised by the memorandum. Our purpose is more modest, namely to present evidence partly with the help of new sources, on three main aspects. These are first the question of the authenticity of the text, and unless there is confidence about that clearly all speculation is arid; second the development of Hitler's views on foreign policy in 1936-37, particularly his view of Britain which is of pivotal importance; and third a comparison of his views with those held by his audience on 5 November 1937. It is obvious that the importance of what Hitler said on that occasion can only be understood by placing it in the context of what other leading figures in the Third Reich thought about the same matters.

The background to the meeting on 5 November 1937 in terms of the immediate dispute over rearmament, and the longer running dispute over the control of the war economy between Schacht and Blomberg on one side and Göring on the other, will not be described in detail because our sources do not add significantly to the established picture $^{4}$. It is necessary therefore to state at the outset, that we do not accept the argument that because the meeting was called to discuss rearmament, it had no bearing on foreign policy. The crisis in the rearmament programme and the problems of Schacht's resignation and succession were intimately involved with foreign policy. It was because of Hitler's commitment to expansion that he would brook no delay in rearmament and this had sparked the domestic crisis. Without the success of rearmament within the specified period, his foreign policy would become impracticable. There is therefore no logic in treating the domestic crisis as an autonomous phenomenon and using it to discredit the importance of what Hitler said. On the contrary, domestic and foreign policy were inter-dependent. The changing fortunes of individuals in the internal power struggles of 1936-38 are symptomatic of that inter-dependence.

This suggests a further dimension to the meeting on 5 November 1937, namely a stage in the assertion of Hitler's authority over his subordinates. This aspect will be considered in detail in the comparison of his views with those of his audience. Hitherto, he had taken charge of individual decisions such as the Polish non-aggression pact, the naval agreement with Britain and the management of the crisis of the reoccupation of the Rhineland. But never before had he challenged his senior professional advisers so fundamentally with his own foreign policy, backed by his own judgement of international politics and strategic opportunities. Again, there seems no reason to doubt that the meeting marked a crucial stage in the definition of the "Führer state ${ }^{5}$.

\section{The authenticity of the Hoßbach memorandum}

Most of the doubts which have been raised concern the suspicion that the Allies may have tampered with the text in order to facilitate the task of the prosecution in Nuremberg. Specifically, it has been alleged that objections raised by Blomberg, Fritsch and Neurath to what Hitler proposed were abbreviated ${ }^{6}$.

The text used at Nuremberg was either a true or doctored version of the copy of the original, made by Graf Kirchbach in Liegnitz in November 1943 and entrusted by him to his brother-in-law, Viktor von Martin ${ }^{7}$. No other version of the memorandum is known to have survived the war. It is assumed that the original perished with the files of the highest levels of the War Ministry which were deliberately destroyed just before the capitulation ${ }^{8}$. Kirchbach's copy was handed over by Martin, according to his later testimony, to Major Thomson the Commanding Officer of the British Military Government detachment in Westerstede, near Oldenburg, in the second half of October 1945. This information appears to be inaccurate since the document had already reached SHAEF [ = Supreme Headquarters Allied Expeditionary Forces] Headquarters early in May 1945 and before Major Thomson reached Westerstede. The only alternative ex- 
planation would be that there was more than one copy of Kirchbach's copy and that SHAEF obtained one earlier and independently of that received from Martin. There is, however, no evidence in the available files that there was more than one source of the document and it seems more likely that Martin mis-remembered the date, and that he in fact handed the document over as soon as Westerstede (if indeed it was there) was captured ${ }^{9}$.

The earliest, extant, datable, copies of Kirchbach's copy were made by the SHAEF G-2 (Intelligence) Document Section. One of these, on a microfilm which included other documents, was sent by the United States' Political Adviser for Germany at SHAEF, Robert Murphy, to the State Department on 25 May $1945^{10}$. Another copy, hitherto unknown to historians, had reached the Foreign Office in London two weeks earlier. The file contains the following entry: "Note: A copy of the German version (typescript) of this Report, and a copy of the corrected translation were sent to $\mathrm{R}$. W. Wheatley at the F. O. Library 11 May 1945. ${ }^{11}$ The State Department copy and the Foreign Office copy are identical: in fact they clearly derive from the same photograph. They both bear the mark »Docs. Center 1a" in the top right hand corner of the first page. The bottom right hand corner of the first page in each is torn. Contrary to the assertions of previous authors, the State Department copy has Kirchbach's signature at the end, as does the Foreign Office copy ${ }^{12}$. The only differences are marks in the margin, which were presumably added when the copies were circulating either by officials of the State Department and Foreign Office respectively or by translators ${ }^{13}$.

These two copies are also identical with the published, German version of the Nuremberg trials which was subsequently used in Akten zur Deutschen Auswärtigen Politik ${ }^{14}$. This is not surprising since the document used at Nuremberg, under the Nuremberg code 386-PS, was itself a copy of a photostat of the film sent by Murphy on 25 May. The only difference concerned Kirchbach's signature. This had baffled officials in the Foreign Office and in Washington and his name was omitted from the published version which ran: "gez. Hoßbach « and on the next line "Für die Richtigkeit:« and underneath "Oberst d. G.". ADAP added the note: "Unterschrift unleserlich " ${ }^{15}$.

The identity of the German text of Kirchbach's copy, which had already reached SHAEF G-2 before 11 May, with the Nuremberg document 386-PS has damaging consequences for the theory that the document was forged. Any forgery must have happened before the 11 th May. This makes the allegation that the forgery was carried out by the American prosecution team impossible to sustain. The prosecution team did not arrive in Europe until the end of May ${ }^{16}$.

The evidence for their treatment of the document does not give any grounds for suspicion either. What appears to have happened is that the section of the prosecution team established in Paris at the end of May under Colonel Robert Storey, with the task of collecting documents for the trial, obtained their own copy of the document there. Its importance was immediately recognized and it was shown to the American chief prosecutor, Robert Jackson, while he was on a visit to Germany in July to find a suitable site for the trials ${ }^{17}$. The document was analysed by Storey's team either in Paris or after it moved to Nuremberg and was given the code 386-PS (standing for Paris, Storey) ${ }^{18}$. The analysis was carried out by Lieutenant Weldon and dated 1 September 1945 . In his report Weldon gave the source of the document as X-2, OSS [Office of Strategic Services], Paris. If accurate, this means that Storey got his copy not from SHAEF G-2 but from the Counter-Intelligence section of the Office of Strategic Services in Paris. This would not be surprising since the collection of odocumentary material relating to the German war effort and Nazi organizations « was one of the tasks of the OSS mission in Germany from 8 May 1945. The natural path for the document to have followed from 
Westerstede would have been to the Headquarters of 21 Army Group in Bad Oeynhausen and from there to SHAEF. OSS probably obtained its copy therefore from SHAEF. It is possible, however, that SHAEF itself received only a copy and that the original of Kirchbach's document was sent from 21 Army Group to the War Office in London or kept in one of the document centres in Germany. Weldon noted that the location of the original as of 1 September 1945 was unknown and that what OSS had supplied was a copy of the original and a translation. He suggested Colonel Hoßbach as a lead for using the document as evidence. In his "Summary ", he observed cautiously "This document, if authentic, is of greatest importance. ${ }^{19}$

The American prosecution team took steps in September and October to obtain a properly authenticated copy of the original. On 7 September, a telegram was sent from the London office of the American team to their Washington office asking urgently for an authenticated copy of the State Department document, together with Murphy's despatch of 25 May. They already knew of the existence of the copy sent by Murphy, because the Washington office (which had received a copy direct from the State Department), had made a summary of it and on 25 June had sent this summary to the prosecution team in Europe. The summary described the document as "an authenticated copy of the originals and went on "The certification of the authenticity is signed by a colonel of the General Staff whose name is illegible. The original is signed by Col. Hossbach ..... It added later "Neither content nor style of the document could justify any doubt concerning its authenticity.« The prosecution team in September asked for a copy of the State Department document on the basis of this summary since it was »better evidence of original than anything found here. "The telegram added "Also need all details concerning source of same and accordingly asked for a copy of Murphy's despatch ${ }^{20}$. The State Department responded by sending a copy of the document, authenticated by Acting Secretary Dean Acheson, on 25 September, followed by an identical confirmation by the Secretary of State, himself, James Byrnes, on 17 October. These authentications described the document as "a true photostatic copy of the microfilm» and added that it had been made available to Murphy by the SHAEF G-2 Document section but also claimed, wholly erroneously, that the microfilm was of »the original German Foreign Office record ${ }^{21}$.

It is not certain why the prosecution team thought that the State Department document would be better evidence than they had already. There are two possible explanations. If the request originated in the London Office without consultation with Paris (or Nuremberg) then it is possible that the officials were working only from the summary they had received from Washington ${ }^{22}$. If on the other hand they had seen Weldon's report then the reason may be that they were misled by the language of the summary from their Washington office into thinking that it was closer to the original than the copy which had been obtained from OSS. It is also possible that what OSS had supplied was a German transcript and a translation not a photocopy. If so, the desire to get the State Department copy was logical ${ }^{23}$.

In any event there is no evidence from the history of the German text to incriminate the prosecution team of forgery. On the contrary, their behaviour was entirely straightforward. Any forgery must have been the work of OSS, SHAEF, or some other Allied agency before the prosecution team got hold of the document.

What grounds are there for thinking that any such organization would have tampered with the document before its first dated appearance in the Foreign Office on 11 May 1945 ? The chronology is against such a theory. It requires one to believe that Allied agencies were already forging documents before or at the time of the German surrender for trials whose form was still far from clear ${ }^{24}$. It is even harder to believe that a forgery 
was produced at that date simply in order to exclude certain objections allegedly made by Blomberg, Fritsch and Neurath to what Hitler proposed, while leaving other objections by each of them still in the document. When it is recalled that Fritsch had been dead since 1939, it seems even less likely. It is much more plausible that Martin and Kirchbach made these allegations in the 1950's to defend themselves against criticism for having provided the Nuremberg prosecution with a key document. Their dismay was natural since their intention had been apparently to provide evidence for the defence, to show how Hitler's senior professional advisers did not agree with his views. Their argument that these objections had been shortened is therefore understandable but not convincing ${ }^{25}$.

There are, however, two gaps in the evidence which lend an air of plausibility to the theory of a forgery. First, the original of Kirchbach's copy was not used at Nuremberg and has not been found. It is impossible therefore to prove, or to disprove, that it is the immediate parent of the State Department and Foreign Office copies. There are two possible explanations of why it is missing. The first is that it was lost or mis-filed by SHAEF, OSS, the War Office or one of the German document centres. In that case it may still turn up ${ }^{26}$. The alternative explanation is that it was deliberately destroyed to conceal the alleged forgery. Which explanation one adopts obviously depends on how probable one finds the forgery theory in the first place. The second gap in the evidence is that no details were given by SHAEF either to the Foreign Office or to the State Department as to where and when the document was acquired. The available sources do not go further back than Murphy's despatch which refers to it only as a captured document and the film as having been provided "following an inspection of the documents by a member of my staff." Whether one regards this gap as further evidence of a conspiracy to conceal a forgery or as further inefficiency is again a matter of judgement ${ }^{27}$. The same applies to the wrong attribution of the document in the authentication by Acheson and Byrnes already noted.

Another argument for the forgery theory rests on the discrepancies between the published English texts of the document. These discrepancies undoubtedly exist and in some cases they include serious omissions. But to claim that these discrepancies point to different English drafts of a forgery which inadvertently appeared in print, thus giving the game away, is a trifle esoteric ${ }^{28}$. The files contain references to and copies of several translations. The Foreign Office file refers to a "corrected translation in the note, dated $11 \mathrm{May}$, and Weldon refers to a translation from OSS. The editors of the collection of trial documents, Nazi Conspiracy and Aggression, themselves note the existence of different translations and the editors of Documents on German Foreign Policy note that they have "retranslated « the document ${ }^{29}$. The Foreign Office file contains two different translations - one of these, headed Annex A, agrees in all but one case with the text published in Nazi Conspiracy and Aggression ${ }^{30}$. Together with Weldon's report, there is another translation, headed "Office of U. S. Chief of Counsel« i. e. the prosecution team, which was certified correct by E. Glazier on 14 November 1945. This translation was not identical with the published versions either in the Trials of The Major War Criminals (IMT [ = International Military Tribunal]) or the Trials of War Criminals although in several cases where they differ from Nazi Conspiracy and Aggression they agree with "Glazier " ${ }^{31}$. In particular, one important omission which has given grounds for suspicion, namely Hitler's reference to the only objection by Neurath recorded in the German text, is already missing in »Glazier«. This no doubt explains why it was also omitted by the American counsel, Sidney Alderman, when he read the document to the court, following the standard procedure ${ }^{32}$. Again this omission can be interpreted either as a deliberate corruption of the text or as a simple error. An error could easily be explained by the fact that both the omitted sentence and the next sen- 
tence in the complete English translation in Nazi Conspiracy and Aggression (and in Annex A) start with the words "In reply to . If the omission was deliberate, it is very odd that the sentence was retained in both Nazi Conspiracy and Aggression and in the published German text. A typing error seems altogether more likely than a conspiracy at once so Machiavellian and so careless!

We consider the arguments that PS-386 was forged by the Allies extremely unconvincing. Of more importance for understanding the memorandum is the question of Hoßbach's motive in making it. Hoßbach was present at the meeting on 5 November 1937 in his capacity as the senior adjutant to the Armed Forces on Hitler's staff. He had been appointed to the position in August 1934 and held it until the crisis of January 1938 when he was dismissed for informing the Commander-in-Chief of the Army, General von Fritsch, of the accusation of homosexuality against him ${ }^{33}$. Hoßbach's loyalties were to the professional army and in particular to Fritsch and the Chief of the General Staff, General Beck, whom he greatly admired ${ }^{34}$. Hoßbach explains that his famous memorandum was not intended as a formal minute but was an unsolicited attempt to record as completely as possible Hitler's lengthy statement with which the meeting began. Hoßbach used notes he made in his diary during the meeting as the basis for his record which he wrote up subsequently and dated 10 November. He twice gave it to Hitler to read through but Hitler refused. Hoßbach mentions that he made only a brief record of the discussion that followed Hitler's statement and he made no attempt to record the details of the second part of the meeting which was concerned with rearmament questions ${ }^{35}$.

Why was Hoßbach so concerned to record Hitler's statement on 5 November? The obvious reason was the importance of what Hitler himself described as his "testamentarische Hinterlassenschaft . It is natural to assume that Hoßbach also wanted a record to show General Beck, who was not present at the meeting. Given Hoßbach's closeness to Beck, he would have been conversant with Beck's critical attitudes and, in particular, Beck's anxiety that German military action in Central Europe would set off a general war, which Germany was bound to lose. On these grounds Beck had already, in May 1937 , criticized a contingency plan for military intervention in Austria in the event of an attempt to restore the Habsburg dynasty. Beck was bound to be acutely interested in the ideas Hitler expressed on 5 November for German expansion and in particular for military action against Austria and Czechoslovakia. Hoßbach's record of the statement did indeed have a profound effect on Beck: he described it as "niederschmetternd « and drew up a detailed critique of Hitler's arguments, dated 12 November ${ }^{36}$.

That Hoßbach's record served, and may well have been intended to serve, a tactical purpose in preparing the ground for a refutation of Hitler's argument in no way detracts from its value as a record. That its existence was known to opposition groups in Switzerland is equally no reason to doubt its accuracy ${ }^{37}$. On the contrary, the tactical purpose makes it clearer why Hoßbach thought it so important to record Hitler's statement correctly.

There is a related question about Hoßbach's treatment of the incident in his memoirs of his period as Adjutant to Hitler. The purpose of the memoirs, as Hoßbach explains, is to provide evidence for the degree of responsibility which should attach to the military leadership for the disastrous course of German policy to 1945. In effect, the purpose is to exonerate Fritsch and, in particular, Beck from blame. As part of this argument, Hoßbach maintained in the final, published version of the memoirs that Hitler gave no indication of his aggressive foreign policy aims to his military leaders before the meeting on 5 November ${ }^{38}$. It is interesting to see, however, that in the first draft (in a passage composed on 8 May 1945) he went even further, arguing that there were »keine Anzeichen bis Januar 1938 [. . .] daß Hitler über die Reichsgrenzen ausgrei- 
fende Pläne für die nächste Zukunft hatte a and that the crisis of Fritsch's dismissal in January 1938 was the real turning point ${ }^{39}$. Of the 5 November meeting, Hoßbach says in this first draft:

"Seine Auffassung über das Verhältnis Deutschlands zur Tschecho-Slowakei hatte er bei einer gleichzeitig Rohstofffragen behandelnden Sitzung mit Blomberg, Fritsch, Raeder, Göring im November 1937 als sein politisches Testament in dem Sinne vorgetragen, daß die Lösung dieser Frage auf weite Sicht ein politisches Ziel sein könne, niemals aber zu einem europäischen Kriege führen dürfe; hierbei noch als Kautele den innenpolitischen Zusammenbruch des parlamentarischen Frankreich voraussehend. An diesen Zusammenbruch glaubte er ebenso wie an den Zerfall des britischen Weltreiches. ${ }^{40}$

Only after his record of the 5 November meeting had been published by Die Wandlung in April 1946, did he change the emphasis of his argument, making it the key date when Hitler first indicated to his military advisers that »er zu einer radikaleren Außenpolitik überzugehen vorhatte « and »die Sitzung [...], die zum entscheidenden Ausgangspunkt für den außen- und innenpolitischen Wandel geworden ist ${ }^{41}$.

Searching for an explanation in retrospect for Hitler's, on this analysis, abrupt change of attitude in November, Hoßbach hit on the influence of Mussolini's visit of 25-28 September 1937 as the most likely reason. Mussolini, according to Hoßbach, behaved on this visit as though he were a military authority whereas Hitler's dependence on his military advisers was obvious. This, combined with Mussolini's foreign policy successes, Hoßbach suggests, must have sharpened Hitler's own ambitions ${ }^{42}$. Hoßbach also in retrospect developed the idea of the connexion between the 5 November meeting and the removal of Blomberg and Fritsch from office in January 1938: both had opposed Hitler's plans for war and both had criticized Göring's management of the Four Year Plan for the shortages of raw materials for rearmament. That was enough to explain the conspiracy against them. Hitler needed to get rid of a determined opponent in Fritsch, while Göring aimed at the same time to overthrow and supplant Blomberg ${ }^{43}$. Even after making these important additions to his argument, however, Hoßbach retained some of the sense of his original version that it had not appeared at the time that the 5 November meeting would lead to action in the near future and that he had not considered it then as of any great consequence. Thus in one passage of the published version, he argues that given the general disposition of Hitler's policy (illustrated by his adoption of a two year conscription period in August 1936 rather than a one year period which would have produced reserves faster and would therefore have been sensible had he planned war in the near future) his statement on 5 November was »um so unbegreiflicher«; and Hoßbach adds: »Immerhin hatte ich im Augenblick den Eindruck, daß angesichts des deutlichen Widerstandes Blombergs und Fritschs mit einer tatsächlichen Verwirklichung der aggressiven Ziele Hitlers nicht zu rechnen war. ${ }^{44} \mathrm{He}$ is also at pains to emphasize that the meeting was not concerned with preparing a concrete plan of campaign but was simply nein erstmaliges Bekanntmachen der höchsten außenpolitischen und militärischen Spitzen mit Zukunftsabsichten Hitlers. " ${ }^{45}$

There is probably more than one reason for the change in interpretation of the 5 November meeting between the first draft and the published version of Hoßbach's memoirs. No doubt seeing his record of the meeting again eight years later, after all that had happened between, did refresh Hoßbach's memory and suggest a new perspective on his story, in particular the connexion to the Fritsch crisis of January 1938, which he continued to regard as the real turning point in the history of the régime, the moment at which he personally had favoured a military revolt ${ }^{46}$. However, it is also clear that the 5 November meeting was something of an embarrassment to Hoßbach's general argument because it did not fit his preferred thesis that there had been no warning of Hit- 
ler's aggressive aims before Fritsch was dismissed. He had instead to show that the military leaders' reaction to Hitler's statement on 5 November had been an appropriate one in the circumstances known to them then.

Hoßbach's defence, most clearly expressed in the first draft written from memory, is very revealing. For the points he picks out, ostensibly that Hitler described Czechoslovakia as a political goal for the long term and one which must never lead to a European war and, it is implied, one which could only be attained if the French Republic collapsed and when the British Empire was too weak to intervene, were indeed the main issues of concern to the military leadership. Their opposition to Hitler's plans was not against the principle of German expansion into Austria and Czechoslovakia but against that expansion being attempted before the armed forces were ready (Beck thought this would be 1940-43 at the earliest) and in a situation which would lead to European war ${ }^{47}$. It was precisely because Hitler's statement on 5 November did not satisfy the military leaders on these points that they objected to it so strongly. If, however, they concluded afterwards that they had succeeded in convincing Hitler of their objections, then it is understandable that they should have put the meeting to the back of their minds since in Hoßbach's words there seemed no danger of a German attack "für die nächste Zukunft « and this had been the chief sticking point for the Generals ${ }^{48}$. That the military leaders did not oppose Hitler's goal of expansion, so far as Austria and Czechoslovakia were concerned, was not a point which Hoßbach was likely to make explicit in writing immediately after the war but it explains his concentration on the conditions necessary for expansion which had been the subject of the disagreement with Hitler ${ }^{49}$.

The different versions of Hoßbach's memoirs are interesting for the light they throw on the way the military leadership reacted to Hitler's statement on 5 November. They do not, however, cast doubt on the text of Hoßbach's record of that meeting. On the contrary, Hoßbach's description of the meeting from memory in his first draft is added confirmation of the text. The phrase "politisches Testament " and Hitler's arguments that Germany could expand without a European war and his statements about the weakness of the French Republic and the decline of the British Empire all agree with the copy we have, although Hoßbach in this first draft changed the sense of what Hitler said from being that Germany could expand without a European war, to being - as the military leaders believed - that Germany could only expand if a European war did not follow. This change of sense is naturally to be explained by the apologia he was writing for his erstwhile military superiors and, by implication, for himself.

\section{Hitler's statement on 5 November}

If we accept that Hitler's statement of foreign policy goals on 5 November deserves to be taken seriously, two questions arise: why did he make it then to that audience and how should one interpret the different parts of his argument? On the first question, the simplest answer has much to recommend it. During 1937 Hitler began to think seriously about how Germany, having re-established its territorial integrity with the re-occupation of the Rhineland in 1936, could go on to the offensive and fulfil the dream of expansion. In that year he had already developed a number of arguments to close party colleagues which he put together in his address on 5 November and revealed for the first time to a group which was not composed of the party faithful (except for Göring) but his service chiefs and Foreign Minister. These were the people whose co-operation he needed to carry out his plans. On this interpretation the address on 5 November was what it appeared to be, an attempt to educate his senior advisers in what lay ahead. This attempt misfired. Blomberg, Fritsch and Neurath were unconvinced and Hoßbach re- 
cords that Hitler's expression showed that he knew he had failed to persuade them ${ }^{50}$. Hitler took no further action immediately, refusing even to read Hoßbach's account of the meeting. New military plans were drawn up and endorsed by Hitler but they made allowance for the Generals' reservations. On 4 February 1938, however, Hitler replaced Neurath with Ribbentrop and took the opportunity of the Blomberg scandal to rid himself of Fritsch as well ${ }^{51}$. Having dispensed with the main opposition of 5 November he resumed the search for expansion against Czechoslovakia (Austria falling to the Reich sooner than Hitler had expected and in a way he had not planned) ${ }^{52}$.

Let us turn now to the question of the interpretation of Hitler's statement as recorded by Hoßbach. It falls into three parts: an introduction where Hitler advanced the case for the acquisition of living space by force in terms familiar from Mein Kampf and the Second Book, with some added detail on Germany's current raw materials and food shortages; a second section where he commented on British (and French) opposition to German expansion; and a final section where he discussed various »scenarios« for a German attack on Czechoslovakia. Against accepting the text as a guide to Hitler's intentions, it has been objected that no mention is made of Russia, the goal of expansion in Mein Kamp $f^{53}$. This can easily be answered, however. Hitler was discussing the first phase of expansion, a phase which his audience found quite alarming enough for him not to elaborate further phases. Even so his words implied further phases: the destruction of Czechoslovakia and Austria were described as "our first goal« to secure Germany's flank for possible operations in the West. It was also clear on Hitler's figures that his goal of living space for one or two generations could not be satisfied by the incorporation of Austria and Czechoslovakia since he said Germany had an annual population surplus of 560000 and Austria and Czechoslovakia would provide food for only 5-6 million people (and that assuming the compulsory emigration of 3 millions from these territories) ${ }^{54}$. Hitler's lack of emphasis on the threat from the Soviet Union is surprising in comparison with the Memorandum on the tasks of the Four Year Plan but Stalin's purge of his generals in the Summer of 1937 may have made this argument seem less convincing ${ }^{55}$. It has also been objected that Hitler's apparent confidence that, for instance, France would not come to the aid of Czechoslovakia and that the Czech defences could be overrun was assumed for rhetorical effect and should not be taken seriously - but as Hitler argued, no expansion was without risk and his major thesis was for German expansion in 1943-45 when its rearmament would be complete ${ }^{56}$.

Hitler's remarks about Britain raise more interesting questions. His argument is as follows. In deciding where it could expand with greatest gain at least cost, Germany had to reckon with two »Haßgegnern«, Britain and France, for whom »ein starker deutscher Koloß inmitten Europas ein Dorn im Auge sei«. Both states "[lehnten] eine weitere deutsche Erstarkung sowohl in Europa als auch in Übersee [ab]«. Britain, he continued, could not give up any part of its colonial territories to Germany because of the opposition of the Dominions and after its loss of prestige by the Italian conquest of Abyssinia, it would not be willing to return the former German territory in East Africa either. The most that Britain would consider would be satisfying Germany's colonial wishes with territories such as Angola which were not British. France would follow the same policy ${ }^{57}$.

However, Hitler then added that this would not always be the case. Serious discussion of the return of German colonies would only happen when Britain faced a crisis and Germany was strong and armed: "Die Auffassung, daß das Empire unerschütterlich sei, teile der Führer nicht.، Britain was not the only global power as Rome had been af- 
ter the Punic wars. On the contrary, it could only defend its colonies by a policy of alliance. How could Britain, for example, defend Canada against the United States or its East Asian interests against Japan? The emphasis put on the Crown as the symbol of the cohesion of the Empire was already an admission that its basis in power could not be maintained in the long term ${ }^{58}$. Hitler instanced Ireland's striving for independence, the constitutional conflicts in India, the weakening of England's position in East Asia by Japan and the conflict with the dynamic power of Italy in the Mediterranean. He concluded that despite its apparent strength the Empire could not be maintained, since the motherland constituted only one ninth of the total Imperial population. Later, in discussing possible German action in 1943-45 against Czechoslovakia, Hitler said he thought it highly probable that Britain (and, he expected, France as well) had already written off Czechoslovakia and accepted that this question would one day be settled by Germany. The difficulties of the Empire and the prospect of being caught up again in a long European war would prevent British intervention and this would deter France ${ }^{59}$.

This lengthy and curious argument raises obvious questions. One can understand the importance for Hitler of being able to demonstrate that Britain and France would not intervene in a continental war against Germany, but why did he feel it necessary to argue emphatically first that Britain and France were opposed to any further strengthening of Germany either in Europe or overseas? This view was in marked contrast to Hitler's professed strategy in the 1920's, to combine a German guarantee of the British Empire with British acquiescence in German continental expansion East. It also appeared to be contradicted by the British Government's willingness to discuss peaceful revision of the Versailles Treaty in Germany's favour.

Again, the simplest answers appear to be correct. First, Hitler believed what he said. He had come to the conclusion both that Britain's ostensible willingness to appease Germany with concessions was a sham intended only to separate Germany from Italy and also that despite its deep-rooted hostility to Germany, Britain was too weak to fight ${ }^{60}$. Second, he had to convince his audience of these views because they did not believe them. They were attracted rather by the idea of a negotiated settlement with Britain and believed equally that Britain was an insuperable global power. To get them to accept his goal of the conquest of living space by force, Hitler had to convince them that they were wrong on both counts. There may have been an additional reason at the forefront of his mind for arguing like this on 5 November 1937. Hitler had agreed on 3 November to meet a British Cabinet Minister, Lord Halifax, a meeting requested by the British Government and put to Hitler by Neurath and Göring. The visit was expected to take place in the near future and Halifax was also to meet Neurath, Göring and Blomberg ${ }^{61}$. There was therefore an immediate incentive for Hitler to make his views about Britain clear to his senior advisers, particularly as they disagreed with him.

There are convincing reasons to explain Hitler's progressive disillusionment with Britain. His original concept of an agreement to share the world had been rebuffed by Britain. The British concept of a general settlement ran exactly counter to Hitler's. Hitler wanted a free hand in Eastern Europe in return for a guarantee of the Empire. Britain wanted a German guarantee of the limits of German ambitions in Eastern Europe, broadly in accord with the principle of self-determination, in return for British agreement to limited revision following this principle and possibly some colonial concessions. The second major development which affected Hitler's view of Britain was the Abyssinian conflict. Originally Hitler had hoped that this would lead Britain to accept German expansion but instead it showed only Britain's inability to restrain Italy without British policy becoming any more favourable to Germany. Italy by contrast emerged with credit in Hitler's eyes by its successful defiance of Britain ${ }^{62}$. 
A new source, the Goebbels diaries, throws fresh light on the development of Hitler's ideas about Britain. Goebbels had regular access to Hitler in the period 1935-37 and made a running commentary on foreign affairs, frequently recording Hitler's attitudes as well as his own ${ }^{63}$. In 1935, Goebbels referred to Hitler's plans for an alliance with Britain and for German expansion East. Hitler looked forward to conflict between Britain and Italy over Abyssinia in the Mediterranean and war between Japan and Russia in the Far East. The conflict with Italy would drive Britain to an alliance with Germany and the conflict with Japan would weaken Russia. The result would be to open the road for Germany to the East. On 19 August 1935, Goebbels recorded a conversation from the previous day after news had been received from Paris that disarmament negotiations had broken down ${ }^{64}$. Goebbels commented that this made war in Abyssinia certain and that the Führer was delighted. Hitler described his plans for some years ahead when conflict would have broken out between Britain and Italy and between Russia and Japan. He intended to ally with Britain, to avoid conflict with Poland, to seek only a limited colonial empire but in contrast to acquire a great though undefined continental empire in the East. The only area to which Hitler laid specific claim was the Baltic but his language implied an unlimited programme of expansion in the East. On 8 June 1936, Hitler repeated his view of the prospects of war between Russia and Japan to Goebbels, Papen (then German ambassador to Austria) and Ribbentrop. He predicted the collapse of Russia in language reminiscent of Mein Kampf and made it clear that it would then be Germany's historic mission to acquire an empire which would secure its needs for a century ${ }^{65}$.

The Goebbels diaries also show the development of Hitler's views of Britain and Italy during the Abyssinian affair. At first Goebbels expected Britain to humiliate Italy and commented smugly that this would serve Mussolini right for letting Germany down in 1934 (i. e. over the abortive Nazi Putsch in Austria in July 1934) ${ }^{66}$. However, as British pressure on Italy increased and economic sanctions were imposed by the League, Hitler saw advantage in mediating. Goebbels recorded that Hitler addressed a large meeting of his Ministers and military chiefs on 18 October 1935 and explained that Germany would try to help Mussolini out of his difficulties rather than join a British programme of sanctions against Italy. Germany was not yet in a position to take advantage of the crisis, Hitler explained, since it needed another three years of rearmament. However, the fact that the international situation was again unstable meant that Germany would have further opportunities to exploit in the future ${ }^{67}$.

This early impression of British strength and Mussolini's weakness gave way in April and May 1936 to the reverse. On 18 April Goebbels recorded that Mussolini's defiance of the League was succeeding and that Britain's decline as a world power had been clearly revealed ${ }^{68}$. This impression was confirmed on 10 May when Mussolini annexed Abyssinia and the failure of British policy and the damage to its prestige was complete. Goebbels drew the conclusion that Britain would now have to seek German support and that Hitler's wish for alliance with Britain was bound to succeed. Hitler, showing a new confidence towards Britain, told Goebbels on 10 May that he would delay replying to a British enquiry about German aims and Goebbels added that Mussolini had been very useful, i. e. in forcing Britain towards Germany. He looked forward to the natural alliance of the two nations who shared a common racial inheritance ${ }^{69}$.

Goebbels remained loyal to Hitler's idea of an alliance with Britain but Hitler himself grew cooler towards it as Italy won his admiration instead. On 5 October 1936, Goebbels recorded that the Führer wanted Italy to leave the League since this would strengthen Germany's position and also that Hitler saw the future in terms of close re- 
lations with Italy and had invited Mussolini to visit Germany ${ }^{70}$. On 21 October, Goebbels noted Hitler's impatience to take sides with the revisionist powers: with Japan through the Anti-Comintern Pact which had just been negotiated by Ribbentrop and by recognizing Manchukuo, with Italy by recognizing Abyssinia and with Franco by recognizing the Spanish National Government ${ }^{71}$. By 9 November, Hitler was also adopting an aggressive tone towards Britain, threatening to take up colonial revision regardless of British sensitivities ${ }^{72}$. And on 13 November, Goebbels recorded that Ciano (Mussolini's son-in-law and Foreign Minister) had made a good impression on Hitler and went on to compare the success of Italy with the lack of leadership in Britain, which was a severe disappointment to the Führer ${ }^{73}$.

Towards the end of 1936 and during 1937 Hitler's position became more definite in three respects: first he showed a growing impatience for action combined with satisfaction at the progress of German rearmament (on 14 November 1936 he told Goebbels that the programme would be complete in 1938) ${ }^{74}$ and, conversely, dissatisfaction with the Auswärtiges $A m t$ for its lack of overall strategy ${ }^{75}$; second, in addition to talk of expansion East and the coming conflict with Bolshevism ${ }^{76}$ Hitler began to discuss the first step, Austria and Czechoslovakia; third, Hitler became convinced not only of Britain's bad leadership but of Britain's decline as a world power and he identified himself ever more closely with Italy, to an extent that made Goebbels uneasy.

On 27 January 1937 at lunch Hitler addressed these themes. He spoke confidently about German rearmament, about the way in which fear of Russia was driving Rumania, Yugoslavia and increasingly Poland as well towards Germany, about the weakness of British leadership (though not of the British people) and of the importance of Italy. He indicated that Germany would be ready for action in six years but that he would take a favourable opportunity earlier if one presented itself (an identical argument to the one he was to use at the meeting on 5 November). Hitler added that France would also like to reach agreement with Germany but in France's case this could only come about when Germany had reached its full strength ${ }^{77}$. On 22 February, Hitler looked forward to a new international order. He spoke of a great conflict again in five to six years time, and he predicted that in fifteen years he would have overcome the balance of power which had existed in Europe since the Treaty of Westphalia. He repeated the Social Darwinian sentiment of Mein Kampfthat Germany would either emerge victorious in the wars of the future or itself be destroyed ${ }^{78}$. Hitler added that Germany would have to choose between Britain and Italy since the British were rearming against Italy and, he asserted, Germany could not be neutral. On 12 March 1937 Hitler addressed a meeting of Gauleiter on relations with the churches, probably instructing them to keep peace on the domestic front in the interests of what Goebbels noted were his revolutionary new ideas in foreign policy ${ }^{79}$. On 14 March, Goebbels talked to the Führer until late in the night and for the first time Hitler spoke of acquiring Austria and Czechoslovakia as a natural extension of Germany's geographical boundaries ${ }^{80}$.

About Britain, Goebbels made frequent references to its incompetent leadership seen in Eden's attempts to prevent the division of Europe into two blocks. Goebbels surpassed himself in uncomplimentary epithets about Eden whom he regarded as ignorant and idiotic $^{81}$. He criticized the inconsistency of British policy in India veering between conciliation and firmness and noted the shock to London of Ireland's declaration of full independence ${ }^{82}$. He dilated on British hypocrisy - the Führer was livid at the English establishment in the abdication crisis ${ }^{83}$; the Foreign Office was found out (as Berlin had suspected) feeding the British press with anti-German stories ${ }^{84}$; Goebbels marvelled at the hypocrisy of a British warning to Franco against interfering with shipping; and of proposals for partition of Palestine, he scoffed that under talk of humanity lay British self-interest ${ }^{85}$. On the other hand, Goebbels was concerned about the scale 
of Britain's rearmament programme, though the Führer's answer to it was simply that German rearmament would be even greater ${ }^{86}$. Goebbels continued to believe ultimately in the wisdom of an alliance with Britain and he criticized Ribbentrop's lack of skill in London and tried to counter Ribbentrop's growing influence over Hitler. However, events conspired against him to push Hitler in the opposite direction ${ }^{87}$.

Two incidents in the Mediterranean stand out in Goebbels' record for their importance in increasing Hitler's sense of independence from Britain. On 30 May 1937 Hitler learnt of the attack on the German pocket battleship, Deutschland, by Spanish Republican aeroplanes, causing injury and casualties. He ordered the Deutscbland and another pocket battleship, the Admiral Scheer, to bombard the Spanish port of Almeria in retaliation and, if possible, to sink the Republican battleship, the Jaime. Goebbels was with Hitler until 3 a. m. and recorded Hitler's fury at the incident ${ }^{88}$. Germany also withdrew from the Non-Intervention Committee until it had received guarantees against a repetition ${ }^{89}$. Four conclusions stand out from Goebbels' account: Hitler's delight at the first demonstration of German armed force; his satisfaction at the support received from Italy; his pleasure at British attempts to placate Germany and finally his disappointment at the timidity of Blomberg and Raeder, who had advised only a protest ${ }^{90}$.

The second incident was similar. On 19 June news reached Berlin that three torpedoes had been fired at the cruiser, Leipzig, by a Republican submarine. This cut short a slight improvement in Anglo-German relations which had been marked by agreement for Germany's return to the Non-Intervention Committee and the announcement that Neurath had accepted an invitation to visit London. Goebbels again recorded that Hitler was furious. Ribbentrop was told to request joint action in accordance with the agreement reached after the Deutschland incident ${ }^{91}$. Neurath's visit to London was called off as a protest against what was seen as British support for the Republican Government. Britain and France refused joint action with Germany and Italy and this incensed Hitler further. He retaliated by withdrawing from the naval patrols and ordering that any Republican ship or aeroplane in the Mediterranean should be fired on at sight ${ }^{92}$. The Leipzig incident reinforced Hitler's unfavourable view of Britain. The British attitude is described by Goebbels as weak, anxious to reach agreement with Germany whose importance is increasingly recognized, but still hypocritically exploiting the opportunity to propose a system of collective security through the Canadian Prime Minister, Mackenzie King. This was naturally rejected by the Führer who saw through the ploy ${ }^{93}$. Goebbels recorded Britain's anger at Germany's refusal to accept that Britain and France should carry out the naval patrols alone and their attempts to pressure Germany by newspaper attacks. But the Führer was unmoved by these tactics and relaxed at the Obersalzberg, keeping London guessing ${ }^{94}$. Hitler explained his revised view of Britain in a lunch-time conversation on $12 \mathrm{July}$. He spoke of the weakness of the British Empire which was now unable to strike Italy. He attributed this weakness to poor leadership and in particular the refusal to choose sides. Britain had pursued the wrong policy in the war and in bringing Germany down, and again in Abyssinia. It was now doing the same in Palestine and alienating the Arabs. These remarks show that Hitler was already thinking about the vulnerability of the British Empire along the lines which he was to develop in more detail to the meeting on 5 November ${ }^{95}$.

The same themes recur in Goebbels' record for July to November 1937. Eden made (in Goebbels' view) characteristically stupid attempts to find a compromise over Spain which would suit everyone but his proposals were rejected by the Soviet Union much to Goebbels' satisfaction ${ }^{96}$. Italy and Japan continued their dynamic foreign policy ${ }^{97}$. An Italian-British rapprochement which Goebbels approved of, since he wanted the friendship of both, came to nothing - Goebbels contrasted Chamberlain's good sense in this policy with Eden's lack of understanding ${ }^{98}$. After war had broken out in the Far East, 
Goebbels recorded on 3 August that the Führer welcomed the prospect of Japan smashing China as that would then leave Japan free to attack Russia. The Führer had decided to stop German support to China and to apply the same principle to Eastern Europe. In future, Czechoslovakia and Hungary would also be treated with harsh realism. The Führer looked forward to the day when he would take over all of Austria and the same fate was reserved for Czechoslovakia ${ }^{99}$. Hitler deliberately raised Germany's demand for colonies at the Nuremberg party rally in September as a sign that Germany was now strong enough to make its presence felt in the world ${ }^{100}$. The Mussolini visit, which followed at the end of September, was considered a great success although he refused to give the Germans the free hand in Austria which they were hoping for. Nevertheless, according to Goebbels, Hitler was entirely satisfied. Mussolini had acknowledged his need for German support and in return bound himself to Germany for the future. Indeed, he had no choice in view of British hostility towards him ${ }^{101}$. In domestic politics, Goebbels noted Hitler's dissatisfaction with Schacht, which had reached breaking point by November, and Göring's suspicions (shared by Goebbels) of the intentions of the armed forces in wanting to preserve their autonomy ${ }^{102}$.

Goebbels talked to Hitler at midday on 5 November before the meeting recorded by Hoßbach which started at 4.15 p.m. He noted in his diary that Germany was not yet in a position to take action against Czechoslovakia but that the Czechs faced revisionist powers on all sides and would not be able to resist their combined strength. The Führer was encouraging Polish ambitions against the Czechs. Goebbels also noted that the campaign on the colonial issue should be moderated in case the public came to expect immediate results which the Government was not yet in a position to deliver. He referred to the proposed visit by Lord Halifax and added, reflecting Hitler's views, that Halifax's purpose was probably to divide the Axis and that in this it would fail. Goebbels had also discussed Schacht with Hitler and they were agreed that Schacht should resign although the Führer wanted to postpone the announcement until after the commemoration of the anniversary of the Munich Putsch on 9 November. The entry ends with the note that Hitler had a meeting with his service chiefs in the afternoon ${ }^{103}$. This entry confirms the view that Hitler did not have an immediate operation in mind against Czechoslovakia on 5 November though he thought Czechoslovakia's position was untenable. The comment that Germany was not yet in a position to take action may have been a result of the warnings Hitler had received about the way the rearmament programme was falling behind, in contrast with his earlier optimism. On the other hand, it could also reflect his calculations about the opportunities that would exist if and when general war should break out in the Mediterranean. The diary entry also confirms that the Halifax visit was on his mind and that he viewed it with scepticism, and that he was still occupied with the dismissal of Schacht.

Despite Hitler's suspicion, Goebbels still hoped that the Halifax visit would be a success and that it would be possible to have the friendship of both Britain and Italy. But this was a vain hope. On 25 November, Hitler gave him a full account of how he had outwitted Halifax. Hitler forced Halifax to take the lead in the discussion by speaking as little as possible. He had thus defeated Halifax's purpose of persuading him to reveal his hand. Hitler raised no demands at all so that now the British were completely nonplussed. The next day Hitler returned to the subject arguing that the British were only interested in negotiations on their terms which were not acceptable to Germany. The British, he said, offered colonies, but not their own colonies, and only on condition that Germany accept a final settlement of its revisionist claims and rejoin the League. The British also offered an understanding on Central Europe and Danzig but, so far as Hitler was concerned, Britain had no right to interfere in these areas. There was therefore no basis for negotiations along the lines offered by Halifax ${ }^{104}$. The negative view 
of Britain prevailed in the remaining diary entries for 1937. Goebbels condemned renewed Franco-British talk of meeting Germany's colonial demands in return for disarmament and return to the League ${ }^{105}$. On 12 December he recorded the Italian decision to leave the League, contrasting the successful partnership of the Axis powers with the discomfiture of the British and French democracies.

The value of the Goebbels diaries as a source for 1935-37 derives from his closeness to Hitler, who enjoyed his company and talked freely to him. Hitler was not committed to everything he said - his remarks about Poland and Hungary for instance were revised as the international situation developed. But certain themes are central and recurrent: his hopes for expansion East, his growing concentration on the initial objective, Austria and Czechoslovakia, and his disappointment with and distrust of Britain. Hitler did not share all his thoughts with Goebbels. Military planning and the detailed direction of foreign policy did not concern the Minister of Propaganda. Goebbels' account is also no doubt coloured by his own views, for instance his dislike of Ribbentrop and his hope that all would be well in the end with Britain. Goebbels was also not privy to all the secrets of the internal power game and he did not see through the conspiracy against Fritsch in January-February $1938^{106}$. However, the diaries do provide a vivid record of Hitler's thinking on foreign affairs and touch on many of the themes which he brought together on 5 November. Perhaps because it caused Goebbels anxiety, the development of Hitler's view of Britain emerges particularly clearly. By 1937 Hitler had come to see Britain as a weakened power, clinging to a concept of its place in the world which was out of date. Its claim to arbitrate in Eastern Europe was an anachronism. Its attempts to entice Germany back to the League by promises of colonial concessions at others' expense were a sham. By the time of the Halifax visit, Hitler's view is one of scorn. Let Britain become enmeshed in the tangled web of its own weaving; it would not catch Germany with its wiles and had no power to stop Germany.

\section{The Dertinger and Kausch reports}

Long familiar to historians but yet to receive the critical study they deserve are the confidential reports of certain German journalists to provide background information for their editors. Based both on official press conferences (particularly those organized by the Propaganda Ministry) and on the journalists' own sources at home and abroad, these reports form a valuable supplement to the Goebbels diaries. Two journalists who provided exceptionally detailed information were Georg Dertinger and Dr. Hans Joachim Kausch. They worked for a collective of provincial newspapers, including $R$ heiniscb-Westfälische Zeitung, the Fränkische Kurier and the Hamburger Nachrichten among others, known as Dienatag ${ }^{107}$. Copies of their reports survive in the files of a fellow journalist, Karl Brammer ${ }^{108}$. These reports place Hitler's views in the context of other views held by Government circles in Berlin, in particular those of the Auswärtiges $A m t$. They provide not only further evidence of what Hitler thought but show how Hitler translated that thought into action by his direction of foreign policy.

At the beginning of 1937, Dertinger interpreted German policy in Spain (though without mentioning his sources) as to gain a negotiating position with Britain by first supporting Italy to the limit Britain would tolerate. The calculation was that Britain could be persuaded to allow Germany colonies (which would help with raw materials) in return for Germany withdrawing support from Italy in Spain. However, the British and French price was much higher: a new West Pact (to replace Locarno), limitation of armaments and guarantees to Eastern Europe - and this was unacceptable to Germany. German policy was therefore to continue to support Italy until Britain relented ${ }^{109}$. At the end of March Dertinger noted that this policy was unchanged despite the Italian 
defeat at Guadalajara and despite the chances for Anglo-German compromise being "gleich $O[\mathrm{Null}] \ll$. However, on 19 April Dertinger reported that the deteriorating position in Spain and Germany's economic difficulties were forcing it to seek an honourable way out. Mussolini, however, had indicated that he would then draw closer to Austria - the threat being »Wenn Ihr Deutschen mich jetzt in Spanien sitzen laßt, dann gestatte ich Euch nicht die Erfüllung Eurer mitteleuropäischen Ziele. ${ }^{110}$ By the next week reporting on Mussolini's »sensationell[en]« support for the German position at his Venice meeting with the Austrian Chancellor von Schuschnigg, Dertinger speculated that Mussolini's price was probably increased German support in Spain ${ }^{111}$. At the beginning of May Dertinger suggested that the recent conversations of Göring and Neurath with Mussolini might prepare the way for a sudden stroke, like the re-militarisation of the Rhineland in 1936, to take the pressure off Italy. He speculated that German intervention in Austria was possible, should revolution break out there ${ }^{112}$.

In May 1937 Hitler intervened personally to make clear that his priority was close relations with Italy and that he did not believe in the possibility of accommodation with Britain. The lack of progress in Anglo-German relations in 1936 and 1937, Italy's need for German support in Spain and Germany's need for Italian support in Austria convinced him that he had nothing to gain and much to lose were he to seek agreement with Britain at the expense of Italy ${ }^{113}$. The occasion for this clarification was the coronation of George VI and, to judge from Dertinger's reports, the sensitivity shown by Mussolini to Blomberg's mission to London as the German representative to the coronation. Hitler's intervention was all the more striking because he reacted in the opposite way to the German diplomats at the coronation who reported hopefully that British opinion was moving towards Germany as it turned against Italy. To appease Mussolini, the Auswärtiges Amt and the Propaganda Ministry played down the importance of the Blomberg visit saying it was only for courtesy; Italy meanwhile registered its displeasure by praising Schuschnigg as »den eisernen Kanzler« of Austria in the Giomale d'Italia ${ }^{114}$.

Hitler acted decisively. On 27 May the German press was instructed to attack at length and in the sharpest terms a Spanish Republican Government "White Book" condemning Italy. German editors were simultaneously warned against the friendly tone of English newspapers, particularly the News Chronicle, which had suddenly mentioned the loyalty of the South Tyrol population to Hitler in an attempt to disturb Germany's relations with Italy. An official of the Propaganda Ministry elaborated on the instructions at a press conference and suggested that the forthcoming visit by Blomberg to Rome should be used to emphasize »die Unabänderlichkeit« of German-Italian relations ${ }^{115}$. On the same day Kausch reported »von unterrichteter Seite« that the instructions came from the Führer himself. He went on:

"Während in den letzten Tagen sowohl vom Auswärtigen Amt wie vom Büro Ribbentrop Informationen ausgingen, die auf ein erreichtes besseres Verhältnis zu England und damit ein positives Ergebnis der Londoner Gespräche schließen ließen, wird jetzt von der höchsten Stelle des Reiches die gegenteilige Order ausgegeben. Der Führer ist anscheinend überzeugt davon, daß die englische Politik jetzt und in absehbarer Zeit darauf gerichtet ist, Deutschland von der italienischen Freundschaft zu lösen, ohne daß England positive Versprechungen etwa in der Unterstützung der Deutschen Südostraumpolitik oder gar in der Kolonialpolitik zu machen brauchte. Alle freundlichen Gespräche und Empfänge in London haben in der Reichskanzlei nicht den Eindruck verwischen können, daß England weder geneigt ist, die kolonialen Wünsche Deutschlands zu befriedigen, noch auch Verständnis zeigt für die österreichische Frage oder das sudetendeutsche Problem. Bestärkt wurde diese Ansicht durch die Ausführungen Edens vor der Empire-Konferenz, die klarstellten, daß das Foreign Office sich am Südosten Europas außerordentlich stark interessiere, selbst bei Gefahr von Konflikten. Diese Meinung des englischen Außenministers wurde ausgesprochen $g e-$ 
gen die Ansicht der Dominienminister und die Dominienminister haben das schließlich auch geschluckt. « ${ }^{116}$

Further confirmation of British opposition to German interests, according to Kausch, was the British attitude at Geneva which allowed the Reds (i. e. the Spanish Republican Government) access to the forum of the League ${ }^{117}$. Finally Berlin knew that the British press had been instructed by the Foreign Office to play up differences between Germany and Italy ${ }^{118}$. Kausch concluded that the attempt to make a new start in AngloGerman relations at the coronation had failed and Germany would support Italy all the more closely. It is striking that the argument attributed to Hitler by Kausch that Britain would support neither Germany's colonial demands nor its desire for expansion in South East Europe is identical with Hitler's argument on 5 November as recorded by Hoßbach.

Hitler's attitude to Britain determined German policy up to and beyond the Halifax visit in November. According to Dertinger, however, the Auswärtiges Amt was allowed to continue with its attempts to find agreement with Britain, such as the proposed Neurath visit in June, on its own account and at its own risk:

"Der Führer sieht den englischen Widerstand gegenüber den deutschen Forderungen sehr viel stärker an, als man es in der Wilhelmstraße zu tun pflegt, wie auch umgekehrt die Wilhelmstraße zu größerem Entgegenkommen an England bereit zu sein scheint, als es der Führer schließlich gestatten dürfte. ${ }^{119}$ After the Leipzig incident Dertinger reported that there were still circles, especially in the Auswärtiges Amt, who wimmer noch auf eine Verständigung mit England spekulieren und von der Zusammenarbeit mit Italien wenig wissen wollen «. He added: "Ich glaube mit Sicherheit erklären zu können, daß diese subversiven Tendenzen nicht die wirklichen Absichten unserer Staatsführung wiedergeben und auch keinerlei Einfluß auf die wirkliche Gestaltung der Dinge gewinnen." ${ }^{120}$

The press was instructed not to mention the Neurath visit after it had been cancelled, even when the invitation was repeated, and this was on the »allerhöchste« (i. e. the Führer's) order. Again in August when it was suggested that to strengthen Chamberlain against Eden the Neurath visit might be revived, Dertinger predicted that German policy would rather be determined by the Führer's "größtem Vorbehalt" towards English gestures of friendliness which he saw as "scheinheilig und unehrlich « ${ }^{121}$.

Pressure from Italy and Japan for more open German support in the autumn put further strain on the Auswärtiges Amt. Italy needed public backing in view of the tough Anglo-French reaction at the Nyon Conference to Italian piracy in the Mediterranean. Mussolini also feared that his admission that Italian forces were serving with Franco might provoke retaliation against Italy ${ }^{122}$. Japan too wanted the Anti-Comintern Pact with Germany to be treated as a military alliance. The Auswärtiges Amt tried to resist this pressure but was overruled by »bekannten Einflüssen« (probably Ribbentrop) and by the Führer himself who from Berchtesgaden let it be known that he was »entschlossen [.. . ] starr an der projapanischen Linie festzuhalten ${ }^{123}$. The Mussolini visit at the end of September further emphasized the close relationship with Italy ${ }^{124}$. Then, on 2 November, Dertinger reported that Ribbentrop had achieved his wish that Italy should join the Anti-Comintern Pact despite the opposition of the Auswärtiges Amt. Dertinger explained in language which reflected Ribbentrop's views that although the title of the Anti-Comintern Pact denoted its main opponent (i. e. the Soviet Union), there was agreement that »vor der Abrechnung mit dem Bolschewismus die Auseinandersetzung - friedlich oder unfriedlich - zwischen den autoritären und den demokratischen Staaten erforderlich ist«. He also noted that although they were outraged by it, the Auswärtiges Amt dared not deny a report in the Corriere de la Sera that the Anti-Comintern Pact did not exclude military co-operation because they were conscious of their "nunmehr schon chronischen Unkenntnis über das was in Wahrheit gespielt wird, da alles vom Führer und Herrn v. Ribbentrop unmittelbar entschieden wird « ${ }^{125}$. 
Lord Halifax's visit at the end of November did not alter the bias which German foreign policy had acquired. Hitler's temper was not improved by an article in the Evening Standard alleging that he would agree to make no colonial demands for ten years provided he was given a free hand in central Europe. Hitler believed, perhaps correctly, that this had been inspired by a Foreign Office source and he retaliated by authorizing and possibly dictating himself a reply in the Nationalsozialistische Parteikorrespondenz which suggested that the visit might be better postponed until the British press had calmed down - thus indicating his lack of interest in meeting Halifax ${ }^{126}$. Dertinger wrote that Chamberlain's purpose in approving the visit was to envelop Germany in a net of treaties, by first showing some willingness to negotiate on colonies and raw materials, and that just as Germany had used the Leipzig incident to avoid this in June, so the present press exchanges showed that neither side had altered its position. The Führer had been particularly annoyed because British press speculation had aroused suspicion in Italy and Japan that Germany might desert them for Britain. He added that the only purpose of giving favourable coverage to the visit was to weaken Eden's position at a time when he was becoming increasingly isolated ${ }^{127}$.

This sceptical interpretation was confirmed, despite optimism in the Auswärtiges Amt, by briefings from Otto Dietrich who had recently been elevated from Press Chief of the NSDAP to Government Press Chief ${ }^{228}$. Dietrich told the journalists (accurately) that Halifax had expressed Britain's willingness to reach an understanding with Germany on colonies and South-East Europe but only within the League. As a result of this »alten Tour «, Dietrich explained, the conversation had been conducted in an icy atmosphere. The Führer's speech in Augsburg showed that he saw no possibility of serious negotiations with Britain in the near future ${ }^{129}$. On 2 December, Dertinger reported that the Daily Telegraph, which he described as the mouthpiece of the Foreign Office, was already stirring up trouble between Germany on the one hand and Portugal and Belgium on the other over possible colonial concessions to Germany. He added a detailed explanation of the Führer's views as communicated by Dietrich:

"Unter Außerachtlassung der Verlogenheit der englischen Politik steht der Führer auf dem Standpunkt, daß selbst eine an sich ehrliche deutsch-englische Annäherung für Deutschland keinerlei konkrete, positive Vorteile in der heutigen Situation bieten könnte. Im Zuge einer deutsch-englischen Verständigung würde günstigenfalls (immer von der englischen Unehrlichkeit einmal abgesehen) Deutschland in den Besitz dieses oder jenes kolonialen Streifens gelangen, den es im Ernstfall nicht verteidigen kann, der, wenn es sich um eine spezielle englisch-deutsche Verständigung handelt, nicht groß genug ist, Deutschland nennenswerte wirtschaftliche Vorteile zu bringen, dessen Größe aber auf der anderen Seite ausreicht, Belgien, Portugal und Frankreich erst recht zu einer antideutschen Einheitsfront zusammenzuführen. Vor allem würde in dem Fall der deutsch-englischen Verständigung Italien seinen ganzen Rückhalt in bezug auf seine Mittelmeerpolitik verlieren und nach Entblößung durch die deutsche Unterstützung in der Tat vor England kapitulieren müssen. Die Folge wäre ein natürlicher italienischer Versuch, sich in Mitteleuropa schadlos zu halten. Rom werde dann automatisch an die Seite Frankreichs gedrängt. Frankreich und Italien zusammen wären dann jederzeit in der Lage, Deutschland auch bei bescheidensten Versuchen einer Neuordnung in Südosteuropa in den Weg zu treten. England würde in diesem Falle nicht in der Lage oder auch nur gewillt sein, nun etwa Deutschland bei der Durchsetzung seiner Mitteleuropa-Pläne gegen den italienisch-französischen Widerstand behiflich zu sein. Die Politik einer Verständigung mit England würde also nur einen effektiven Kolonialerfolg bringen, aber real die Unmöglichkeit südosteuropäischer Expansionspolitik zur Folge haben. Aus diesen Überlegungen kommt der Führer zu dem Schluß, daß Deutschland unverändert auf der Seite Italiens stehen bleiben muß und kein Interesse daran hat, zu einer Verständigung mit England zu kommen. Nur solange der Eisblock zwischen Berlin und London besteht, ist Italien in der Lage, Mittelmeerpolitik zu treiben und dafür in Mitteleuropa gegenüber Deutschland stillzuhalten." ${ }^{130}$ 
The similarity between the argument here as to what colonial concessions Germany might hope to gain with British support and the corresponding section of the Hoßbach record is unmistakeable. The second argument developed by Hitler, the candid exploitation of Italy's involvement in the Mediterranean, also appears in the Hoßbach record in the more specific form that German interests lay in the prolongation of the war in Spain in the hope that general war would break out there, when the Führer would »unter Ausnutzung dieser sich nur einmal bietenden günstigen Gelegenheit den Feldzug gegen die Tschechei beginnen und durchführen [.. . «. To achieve this end, "müsse es Aufgabe unserer Politik in nächster Zeit sein, Italien den Rücken für weiteren Verbleib auf den Balearen zu stärken« which would be »weder für Frankreich noch für England tragbar ${ }^{131}$.

The reports of Dertinger and Kausch highlight Hitler's suspicion of Britain and his determination to support Italy. The parallel between Hitler's instructions to the press at the end of May and again in November and December 1937 is striking. On both occasions Hitler chose to soothe Italian fears rather than explore negotiations with Britain. Together with Goebbels' diary, the reports corroborate Hoßbach's record of Hitler's views: that Britain was opposed to German expansion but too weak to do anything about it and that Italian involvement in the Mediterranean offered an opportunity for German action. The reports also suggest that Hitler's views were resisted by the Auswärtiges Amt. It remains to consider this last aspect more fully, to place Hitler's statement of 5 November in the context of the range of views held by other leading figures in the Third Reich.

\section{Alternative Views:}

\section{Hitler's professional advisers}

The most open advocate of an alternative foreign policy to Hitler's had been his Minister of Economic Affairs, Schacht. His support for expanding foreign trade and regaining colonies to solve Germany's economic problems was well-known. In August 1936, claiming Hitler's authority, he had proposed to the French Government a settlement on these lines; but when this was put to the British Government, Eden was non-committal ${ }^{132}$. In February 1937 Schacht repeated his proposals to a British official, warning that if Germany's economic difficulties were not solved this

"would only strengthen the hands of the wild men, who would then work for some sexplosion. Hitler was at present open to argument and if he (Dr. Schacht) could show that other means were available to give Germany a chance, he was convinced that he would be able to get Hitler to take that chance and to give us the guarantees which we wanted.« 133

In fact, Hitler had no intention of giving the guarantees which France and Britain wanted, i. e. a "general settlement « tying his hands in Western and Eastern Europe in return for colonial concessions. Hitler regarded colonies as a separate issue over which Germany should receive justice as of right, not in return for giving up other goals which, in addition, he saw as more important ${ }^{134}$. By May 1937 Hitler had come to the accurate conclusion that Britain in any case did not then intend to make significant colonial concessions to Germany (and as a result neither would France) ${ }^{135}$. The only effect of Schacht's initiatives would therefore be to annoy Italy and help Britain split the Axis. Before Schacht travelled to Paris for discussions on 25-29 May, he appears to have been told by Hitler to stop his private foreign policy. In Paris, uncharacteristically, Schacht merely recorded the views of the French Government without offering any of his own ${ }^{136}$. 
In the summer of 1937 Schacht's authority rapidly declined. His long standing feud with Göring as head of the Four Year Plan was not solved by Hitler's attempts to prevent his resignation. Hitler wanted to keep Schacht not because he liked his policies but because he was uneasy about replacing him. Were Schacht's removal to lead to any further increase in Göring's power, there would be opposition from within the party and elsewhere. Hitler had no wish to provoke such opposition, and may in any case have thought Göring powerful enough already ${ }^{137}$. We know from Goebbels that what to do about Schacht was on Hitler's mind at the beginning of November and that on the 5th he told Goebbels that Schacht must go but that he was going to postpone the matter until after the commemoration of the anniversary of the Munich Putsch on 9 November ${ }^{138}$. Schacht himself was open about the failure of his attempt to influence foreign policy. In a conversation with the American ambassador to France, Bullitt, on 18 November, he spoke of his fear of war, his lack of influence with Hitler and of Hitler's fury with Britain. On 20 November, aware that his resignation had finally been accepted, Schacht again talked of a colonial settlement to Halifax, now at the expense of Belgium and Portugal, but added (according to Halifax's record) that »We [i. e. Britain] had missed the bus - which had Hitler's personal authorisation - a year ago, when he had his discussions with Blum [...].«" ${ }^{139}$

The introductory section of Hitler's statement on 5 November 1937 reads like a final reckoning with Schacht in its argument for the conquest of living space and its rejection of the alternative of increased foreign trade and the »liberalistisch-kapitalistischen « view that space could be sought not in Europe but in the exploitation of colonies. The passage about British (and French) unwillingness to return colonies also reads as though it was intended as the epitaph on Schacht's efforts ${ }^{140}$. This would have been well understood by his audience and suggests that Hitler knew they shared some of Schacht's assumptions and was issuing a warning that these would no longer influence German foreign policy.

The Auswärtiges Amt under Neurath also had its own views which differed from Hitler's in important respects, although its resistance was more muted than Schacht's. Unlike Schacht, Neurath did not believe in the priority of the colonial issue. He told the British Ambassador, Sir Nevile Henderson, on 21 May 1937 that the

"colonial question was Dr. Schacht's hobby. He assured me that it was entirely secondary. He repeated this several times. Nor was that, he said, only his opinion but also largely Herr Hitler's [... . Herr von Ribbentrop had made much of the colonial question because he wanted to win his spurs but Herr Hitler looked at it from quite a different angle. ${ }^{141}$

For Neurath and the Auswärtiges Amt, German expansion in Central Europe was the crucial goal and this meant Austria, the break-up of Czechoslovakia, Danzig and the revision of the Polish frontier: a colonial empire was desirable but not a high priority ${ }^{142}$.

For the professional diplomats the central question was how to bring about this revision of the Treaty of Versailles without another European or World War, a war against France, Britain and perhaps the United States on one front and against the Soviet Union on the other. Britain was seen as the key to the situation, both because of its global power and because if it could be persuaded to acquiesce in German expansion it would have a restraining influence on France. Nevertheless, during 1936-37, Neurath went along with Hitler's increasingly pro-Italian policy. The reason for this, as Dertinger and Kausch correctly surmised, was tactical: to improve Germany's bargaining position. Neurath may also have hoped to gain credit with Hitler at the expense of his rival Ribbentrop, who from August 1936 until he gave up the attempt a year later, was trying to win over the British Government to support of German expansion in Central 
Europe. Neurath, who had himself been Ambassador to London in 1930-1932, considered this attempt premature since Germany did not yet command sufficient power to attract British support ${ }^{143}$. But as, from May 1937, Hitler moved towards a policy of exclusive support for Italy and abandoned hope of agreement with Britain (a policy also adopted by Ribbentrop once he had given up hope of scoring a personal success in London), so the professional diplomats in the Auswärtiges $A m t$ became increasingly uneasy.

The German ambassador to Rome, Ulrich von Hassell, was explicit about the dangers. In April 1937 he warned against provoking the Western powers and the United States since, together, they would be much more powerful than Germany and Italy and might have the support of the Soviet Union as well. Over-emphasis on the Axis could lead to "einer bewußten Einkreisungspolitik" on the part of the other powers ending in war and Italy, the weaker partner, might leave Germany in the lurch as had happened in 1914-1918 with Austria. Germany had cause

»mit größter Nüchternheit die Kräfteverhältnisse zu betrachten« and this would show the need »eine unsere Interessen wahrende Verständigung mit England als unbedingt erstrebenswertes Korrelat der Achse Berlin-Rom im Auge zu behalten [. . . ]«. Neurath noted in the margin by "größter Nüchternheit", "tun wir" and at the end of the dispatch, »Alle diese Erwägungen haben wir natürlich auch angestellt $u[$ nd] richten unsere Politik danach. « ${ }^{144}$

From May 1937, Neurath tried to moderate Hitler's exclusive enthusiasm for Italy and keep open a channel for negotiations with Britain. In a conversation with the League High Commissioner for Danzig, Burckhardt, he echoed Hassell's warning: "Germany", he said "had no intention of committing on behalf of Italy today the error that she had committed on behalf of Austria in 1914, that is to say being involved in a European war as an outcome of the activities of her southern partner. " ${ }^{145}$ Neurath exercised a restraining influence on Hitler in both the Deutschland and Leipzig crises ${ }^{146}$ and responded favourably both to the British invitation to him to visit London in June (a visit blocked by Hitler) ${ }^{147}$ and to the British desire for Halifax to visit in November ${ }^{148}$. He opposed Ribbentrop's pressure for closer identification of Germany with Japan in the Far East and for the extension of the Anti-Comintern Pact between Germany and Japan to include Italy ${ }^{149}$.

The clearest statement of the divergence of the Auswärtiges Amt from Hitler comes, however, not from Neurath (who confined himself in sensitive questions to commenting on the views of others) but from the then director of the political department, Ernst von Weizsäcker. Before Mussolini's visit in September he had warned of the dangers of "Bindung an italienische Abenteuer« and »italienischer Verkauf unserer Freundschaft an England ${ }^{150}$. On 10 November he complemented this by a memorandum in preparation for Lord Halifax's visit which reasoned as follows:

»Einen Krieg mit England als Gegner können wir auf lange hinaus nicht ins Auge fassen. Was wir von England wollen, können wir uns nicht gewaltsam holen, sondern müssen es einhandeln.

Wir wollen von England Kolonien und Aktionsfähigkeit im Osten, England wünscht von uns militärisches Stillhalten, namentlich im Westen. Diese Wünsche sind nicht völlig unvereinbar. Ein Ansatz zum Verhandeln läßt sich finden, wobei die konkreten Ergebnisse zunächst minder wichtig sind als der Zweck, die antideutsche Front in London nicht erstarren zu lassen.

Das deutsch-englische Verhältnis läßt sich m. E. ohne Schaden für unsere sonstigen Beziehungen um etliche Grade bessern. Das englische Ruhebedürfnis ist groß. Es lohnt sich festzustellen, was England für seine Ruhe zahlen will. Allerdings läuft in Rüstungsfragen die Zeit für England, nicht für uns. Daher haben wir nicht beliebig langen Verhandlungsspielraum. « ${ }^{151}$ 
This advice was in marked contrast with the views Hitler had expressed on 5 November both in arguing that Germany must negotiate and that negotiations had a chance of success. Behind this difference of view lay a difference in ultimate objectives. The professional diplomats thought in terms of expansion in Central Europe and colonies; Hitler thought of living space for several generations at the expense of Russia. It was much more credible that the former could be achieved by negotiation than the latter.

There were, however, serious problems with the Weizsäcker strategy. First, although he thought they had a chance, he was not optimistic about the negotiations succeeding. His argument that Britain wanted peace, "namentlich im Westen" was his reason for hoping that Germany might be allowed to expand sim Osten". But the stumbling block was that Britain wanted a "Gesamtregelung" and this was likely to tie Germany's hands in the East in a way which would prevent the realization of even the limited goals of the Auswärtiges Amt let alone Hitler's ${ }^{152}$. The problem here was less Austria (which was more a question of German-Italian relations) than Czechoslovakia ${ }^{153}$. The Auswärtiges Amt accepted Hitler's aim of the destruction of Czechoslovakia because they saw it as a military threat in view of its treaties with France and the Soviet Union. But they had to admit that Britain and France seemed a long way from agreeing to this aim by December $1937^{154}$. They probably also shared some of Hitler's scepticism about British motives in seeking talks with Germany, particularly the fear that Britain wanted to split the Axis and buy time.

There was a further acute problem for the Auswärtiges Amt, clearly reflected in Weizsäcker's memorandum of 10 November. He argued both that Germany could not consider a war with Britain for a long time and also that time in rearmament was on Britain's side not Germany's. This meant that negotiations would have to be conducted on the basis of Germany's relative and worsening military inferiority. This cannot have looked promising. In another memorandum, on 20 December 1937, Weizsäcker therefore supported negotiations with Britain to give Germany "politische Positionsgewinne", since time in terms of military and economic power was not on Germany's side. No agreement, he continued, was possible with France so long as she threatened Germany »vom Osten her durch Allianzen«. He went on about Britain:

„England schwankt heute noch, ob es nicht seine Ruhe in Europa durch Abschlagszahlungen an Deutschland erkaufen sollte. Man muß bezweifeln, ob sich ein geeigneter Kaufpreis findet. Unser Verhalten wird aber unabhängig von diesen Zweifeln zu bestimmen sein. England möglichst lange im Zustande des Schwankens zu erhalten, ist dem Zustand seiner entschlossenen Feindschaft gegen uns gewiß vorzuziehen."

Neurath commented here that Britain's decision would depend on developments in the Far East and that the German interest was "die vorhandenen Reibungsflächen im Mittelmeer und in Ostasien nicht zu schnell zu beseitigen ${ }^{155}$.

The Auswärtiges Amt view could be summarized as follows: war with Britain could not be contemplated; on the other hand time for negotiations was limited and the chance of their succeeding slight; the best that could be hoped for was to keep the prospect of talks alive and to see that pressure on Britain in the Mediterranean and the Far East was maintained in the hope that this double-edged policy would bring Britain round.

Hitler too believed that time was not on Germany's side but he had no faith in negotiations. Rather he had reached the logical conclusion that Germany should solve its problems by force while its relative strength was greatest. As he is reported to have commented to Ribbentrop after reading some private remarks of Churchill's from 1936 about maintaining the balance of power in Europe:

»Ich wette mit Ihnen, in fünf Jahren ist Churchill Premierminister - und dann haben wir den Salat! Ich kann Ihnen jedenfalls versichern, daß ich nicht warten werde, bis man mich eingekreist hat. Ich schlage zu, ehe es zu spät ist, und zerreiße die Netze, welche die englische Spinne um mich weben will.« ${ }^{156}$ 
The inclusion of Neurath in the meeting on 5 November, which would not have been necessary had the meeting simply been concerned with rearmament, was probably because Hitler was well aware that Neurath did not share these views. Hitler hoped either to win him over or possibly (as Raeder later suggested) to provoke his resignation ${ }^{157}$. Neurath had recently adopted positions which were unwelcome to Hitler both over Italy and Britain. He had opposed the extension of the Anti-Comintern Pact to Italy which was to be concluded by Ribbentrop in Rome the following day. Neurath, together with Göring, had also put the proposed Halifax visit to Hitler on 3 November which, given Hitler's views of Britain, can scarcely have pleased him ${ }^{158}$. Against this background, the inclusion of Neurath on 5 November can be seen as Hitler taking the opportunity to deliver a calculated appeal (or warning) to him to conform.

Not surprisingly the aspect of Hitler's address which alarmed Neurath was the argument for the early use of force. This contradicted Neurath's policy of trading support for Italy for a bargain with Britain. Hitler made it clear that there was to be no deal and that the Axis was not a bluff to bring about negotiations but a division of spheres of interest on which his plans for war depended ${ }^{159}$. It was therefore logical for Neurath to question whether an Anglo-French-Italian conflict in the Mediterranean was as close as Hitler seemed to assume. Whether Neurath also understood that Hitler had plans for expansion far beyond Austria and Czechoslovakia, and if so whether he took such ideas seriously, is not clear but it seems unlikely ${ }^{160}$. In his defence at Nuremberg Neurath said he had been shocked by Hitler's statement, that he had discussed it some two days later with Fritsch and Beck and that they had agreed that Fritsch should raise the military objections with Hitler and Neurath would put the political objections. Neurath claimed that when he was next able to see Hitler, about the middle of January, he warned Hitler that his policy would lead to world war and also tried to persuade him that many of his plans could be realized by peaceful means though more slowly. Hitler replied that "he could not wait any longer" and Neurath's replacement by Ribbentrop followed on 4 February $19388^{161}$.

There is every reason to suppose that the views of the Auswärtiges Amt were shared by Blomberg and Fritsch. In the discussion on 5 November both naturally concentrated on the military aspects of Hitler's proposals. According to Hoßbach's record, they "wiesen [...] wiederholt auf die Notwendigkeit hin, daß England und Frankreich nicht als unsere Gegner auftreten dürften [...]«. Fritsch estimated that even if France were involved in war with Italy, French forces would still have superiority on the Western frontier. Blomberg emphasized the weakness of German fortifications in the West and of the motorized divisions there and he also drew attention to the strength of Czech defences ${ }^{162}$.

Their fears had no doubt been heightened by the British rearmament programme whose importance had been recognized by the German military attaché in London, Geyr von Schweppenburg. Geyr had no doubt that Britain considered Germany its most dangerous potential enemy and that British rearmament, which he described as "ohne Vorgang in der englischen Friedensgeschichte«, was aimed primarily against Germany ${ }^{163}$. In his last report from London, dated 20 September 1937, he argued that up to the end of 1938, when British air and naval rearmament would be substantially complete, it might be possible for Germany to score some successes without precipitating war. During this period economic or even territorial concessions might be negotiated, but it was unlikely that Germany would be allowed decisive military superiority in Europe. In the event of war with Britain and France, Germany might also be successful for a time but, Geyr emphasized, once British air and naval forces could protect the motherland and sea routes, "Es ist nicht möglich, einen Krieg gegen das britische Reich zu gewinnen [...]« According to Geyr, Fritsch went through this report with him line by 
line but Blomberg, who had the previous December encouraged him to talk frankly to Hitler (while preferring not to do so himself) avoided seeing him ${ }^{164}$.

Blomberg, although lacking the character to stand up to Hitler, tried to promote good relations with Britain. He had been chosen as the German representative to the Coronation and seems to have thought that he had been given a serious mission to improve relations between the two countries, telling Eden that he was acting on definite instructions from Hitler. He must have been disconcerted to discover on his return that Hitler was more interested in Mussolini's reaction and that he was to be dispatched immediately to Rome to make up for his trip to London. According to Hoßbach, Blomberg was extremely angry at the way his London visit had been discredited and said he would not accept another mission ${ }^{165}$.

Blomberg also supported Neurath in counselling moderation to Hitler during the Deutscbland and Leipzig incidents ${ }^{166}$. When Halifax visited Berlin in November, Blomberg reflected Hitler's views telling Halifax that the colonial issue was secondary and that »the vital questions for Germany, with her expanding population and set as she was in the middle of Europe, were those which concerned her Central and Eastern European position. « He appealed to Halifax for Britain to be realistic and accept German expansion, adding that Anglo-German understanding was the »basis of peace and that Hitler still desired good relations, his present resentment being that of "a scorned lover “ ${ }^{167}$. These remarks betray both Blomberg's knowledge that Hitler was committed to expansion and his anxiety about war with Britain.

A much more determined opponent of Hitler's schemes within the army command was the Chief of the General Staff, General Beck. He had discussed with Fritsch and Neurath what was to be done about Hitler's alarming statement of 5 November. Having subsequently read Hoßbach's memorandum, Beck wrote a refutation of Hitler's views on 12 November possibly meant for an oral presentation to Blomberg. Beck understood Hitler to have been talking only about expansion in Central Europe with Austria and Czechoslovakia as the first stage, which suggests that Fritsch and Neurath also interpreted Hitler's remarks in this way. They were, of course, aware of the danger of war with the Soviet Union arising both from German ambitions in Central Europe and from the ideological enmity between Nazism and Communism. But they did not apparently see in Hitler's remarks the intention to establish a base from which a racial war against the Soviet Union could be conducted ${ }^{168}$. Beck did not dispute that Germany had a "Problem des Raumes« and that it was desirable "den Fall Tschechei (evtl. auch Österreich) bei sich bietender Gelegenheit zu bereinigen [...]«. By this he meant the destruction of Czechoslovakia in order to remove its strategic threat. As a result Germany, with the inclusion of Austria, would become the preponderant power in Central Europe. Beyond this aim, Beck cast doubt on the feasibility (and desirability) of farreaching territorial change in Europe and argued that since economic autarchy was impossible, Germany must maximize its foreign trade. He also rejected Hitler's explanation of the tactics of expansion and dismissed Hitler's conclusion that Germany's space problem must be solved by $1943-45$ as min seiner mangelnden Fundierung niederschmetternd « though he later substituted »nicht überzeugend«. On Hitler's argument about Britain, Beck commented:

"Die Größe der Gegnerschaft Frankreichs und Englands gegen einen Raum- und Machtzuwachs Deutschlands sei nicht verkannt. Die Gegnerschaft jedoch als unumstößlich bzw. unüberwindlich anzusehen, erscheint nach dem bisherigen völlig unzureichenden Versuchen ihrer Beseitigung nicht am Platze. Die Politik ist die Kunst des Möglichen, alle drei Völker sind zugleich auf der Welt, noch dazu in Europa, da heißt es doch wohl zunächst alle Möglichkeiten, sich zu arrangieren, zu erschöpfen, zumal angesichts des gegenseitigen Stärkeverhältnisses. Außerdem ist es auch für den Fall eines späteren Bruchs klüger.« 
He continued, echoing the views of Geyr von Schweppenburg,

"Sicher ist das Empire nicht unerschütterlich. Die Wahrscheinlichkeit, daß es noch bis auf weiteres die bestimmende Weltmacht neben Amerika ist, erscheint mir jedoch bei weitem größer. Und daher wird auch England bis auf weiteres nicht allein stehen, sondern stets Bundesgenossen haben. ${ }^{169}$

It is worth adding in parenthesis that the concern aroused by Hitler's statement on 5 November in the army command appears not to have been shared by the navy. Raeder did not intervene in the discussion to support Blomberg and Fritsch. He claimed at Nuremberg that this was because he had repeatedly made it clear to Hitler that there must be no conflict with Britain which in terms of Germany's naval strength would have been "sheer madness « ${ }^{170}$. This was undoubtedly correct but Raeder's calculations were more complicated. Naval planners had already come to the conclusion that British participation in a future war against Germany could not be ruled out. After the 5 November meeting Raeder decided to use the increased steel allocation, which he had succeeded in obtaining, for submarines because of the expected worsening of relations with Britain ${ }^{171}$. Without the record of the rearmament section of the 5 November meeting, Raeder's arguments can only be guessed at. Clearly Hitler's statement that Britain and France were implacably opposed to German expansion pointed to naval rearmament, as well as other measures, if only as a deterrent. Raeder who wanted a greater role for the navy and who had pressed for the meeting to take place would naturally not have wanted to challenge Hitler. He was probably happy to leave his army colleagues to voice their concern. Not only did he get what he wanted on 5 November but unlike Blomberg, Fritsch and Neurath, he kept his post in February $1938^{172}$.

\section{General Göring.}

The only member of Hitler's audience on 5 November with roots in the Nazi party was General Göring. Despite his close personal and political ties to the Führer, however, Göring does not appear to have shared Hitler's ambition for a racial reconstruction of Europe. His background and outlook were rather those of a traditional nationalist and his aim was concentrated on establishing a German national state in Central Europe with a South East European bloc of dependent states to supply the economic deficiencies of the Reich. It is possible to see in this goal also the preparation of a launching pad against the Soviet Union. Certainly anti-Communism was the heart of Göring's ideology and the economic resources of the Soviet Union were no doubt attractive to him. But unlike Hitler he does not appear to have seen conquest of the Soviet Union as a racial imperative ${ }^{173}$. He also took the danger of British and French intervention against Germany seriously from May 1938. As the executant of the Four Year Plan, and of its extension in 1938 to include preparation against Britain, he knew that Germany would not be ready for war with the Western powers until the mid-1940's. As a result, after the Munich agreement in September 1938, Göring became relegated to the side-lines of foreign policy since Hitler did not share his pessimism and turned instead to Ribbentrop for support ${ }^{174}$.

From 1936 to the Anscbluß in March 1938, Göring was at the height of his power. He pursued his economic and foreign policies with energy and ruthlessness. He clearly hoped for British consent to his programme for a greater Germany in Central Europe ${ }^{175}$. As Hitler became increasingly belligerent during 1937, Göring grew more anxious to persuade Britain that German expansion was inevitable and that this involved no threat to the British Empire. Like Neurath and Blomberg, therefore, Göring did not share the indifference towards Britain which Hitler expressed on 5 November. In the discussion of Hitler's statement, according to Hoßbach's record, Göring said only that 
Germany should consider liquidating its military undertakings in Spain. This can be interpreted either in terms of the need to concentrate German forces for the attack on Czechoslovakia (Göring no doubt had in mind the important Luftwaffe commitment in the Condor Legion), or as a way of giving effect to Hitler's declared aim of prolonging the war in Spain rather than helping Franco to an early victory ${ }^{176}$. Beyond this comment, Göring appears to have remained silent until the meeting moved on to the discussion of rearmament. It is possible that he did not support Blomberg because he was inclined to discount Hitler's talk of using force (as he claimed at Nuremberg) but more probable that he wanted to protect his position with Hitler and to undermine Blomberg, with whom he was in conflict over the rearmament programme.

During 1937, Göring used his influence to prepare the way for an agreement with Britain. In conversations with Lothian, Henderson, Halifax and the former British air attaché in Berlin, Group Captain Christie, he pressed the familiar arguments for a division of spheres of interest. His central point was respect for the British Empire wwhich he thought a great and stabilising influence for world peace « ${ }^{177}$ and for whose defence if necessary Germany was willing to lend half its army ${ }^{178}$. Göring let it be understood that he would much prefer an agreement with Britain to the Axis ${ }^{179}$. On the other hand he also made it clear that the German price would have to be paid. To Henderson, he talked of Germany's rights to Austria and the Sudetenland and in time to a revision of the frontier with Poland; but to Christie, perhaps because he was an old acquaintance, he was extraordinarily frank in saying that Germany must have Bohemia and Moravia (not just the Sudetenland). To talk like this in 1937 was a clear admission that Germany intended to go to war with Czechoslovakia. Presumably Göring thought that the best way to avert British intervention was to be as frank as possible in advance. Göring gave Christie further details of his plans for the new German state. It would not include Slovakia, where Hungary and Poland would be allowed to expand, but to it would be added an anti-Communist bloc of "partners« or "dependencies« in South-Eastern Europe consisting of Hungary, Rumania, Yugoslavia and Bulgaria. Colonies were a "subsidiary « issue. The crux was Czechoslovakia: „England must realise that; in the end it's a question of Czechoslovakia or England. «180

In his insistence on the price, Göring was probably reflecting both his own hopes of what would be possible and the pressure which arose from Hitler's impatience with Britain. Christie was also able to discover, however, the economic reasons for Göring's concern about Anglo-German relations. As director of the Four Year Plan, he knew that Germany could not survive a long war ${ }^{181}$. As Commander-in-Chief of the Luftwaffe, he also knew at first hand the serious effect of steel shortages on air rearmament. His State Secretary, Erhard Milch, in a report for the rearmament discussion on 5 November, argued that the shortfall in iron and steel would set back some aspects of the programme for the next five years by as much as a further five years ${ }^{182}$. This made the increasing influence of pro-Italian party »radicals on Hitler all the more dangerous. Göring's comments to Christie on this score at the Nuremberg party rally in September 1937 may well have betrayed his real fears. Christie noted:

»Army's position in State a[nd] Foreign Policy lessened: Radis at moment around Hitler. Göring realises now risk war brings Reich. Schacht's departure means greater drive into military Autarckie [sic] Göring and Army against Alliance with Italy, Party Radis strong for it. Hitler, when in petulant mood, too easily egged on by Radi taunts and flattery. $\$ 183$

Given Hitler's view of Britain there was not much Göring could do other than trying to win Britain over or alternatively limiting the damage, by explaining Hitler's disappointment to his British visitors and keeping a channel for negotiations open. The result of his complaints over alleged British obstruction was that the Foreign Office pressed 
Henderson to ask Göring for specific examples, which meant defining precisely what German policies were. Not surprisingly Göring said only Hitler could do that, though he explained his own views to Henderson in the terms discussed above and suggested, in October, arranging for Henderson to talk directly to Hitler ${ }^{184}$. This proposal was then superseded by Halifax's visit which Göring helped to arrange ${ }^{185}$.

Göring was not above lying about Hitler's views, as when he told Henderson on 6 November that he had seldom heard Herr Hitler speak more enthusiastically in favour of an understanding with Great Britain«. He was also clearly nervous about the difference between his approach and Hitler's, asking Halifax not to say in conversation with Hitler that »Göring told Henderson something quite different « ${ }^{186}$. Göring was also disingenuous in his remarks to Christie, implying that he like Schacht was opposed to the policy of autarchy whereas in fact he was manoeuvering to take over from Schacht; similarly he implied that he sided with the army command against the party radicals, at the same time as he was complaining to Goebbels about the army's influence and aspiring to replace Blomberg himself.

However, Göring's unscrupulous intrigues do not affect the reasons for thinking that he disagreed with the policy Hitler laid out on 5 November 1937. In particular, he did not believe that Germany should give up trying to reach agreement with Britain. He may well have been encouraged by Halifax's comment to Hitler on 19 November that the British Government would be willing to see change in the status quo in Danzig, Austria and Czechoslovakia ${ }^{187}$. Göring could be forgiven for thinking that his efforts with Henderson and other British visitors were bearing fruit and that, contrary to Hitler's disparaging view of it, the Halifax visit showed that agreement with Britain was still possible. Göring's renewed pressure on Austria and his own leading role in bringing about the Anschluß in March 1938 show his confidence that Britain would not resist $^{188}$. He may have hoped that by demonstrating British acquiescence, he could win Hitler back to a more favourable view of Britain.

Similarly, in his bid to replace Blomberg in February 1938, Göring may have hoped that he would have a stronger influence on policy and offset the "radical " Ribbentrop. Hitler who had no desire to strengthen Göring's position further and who was aware of Göring's reservations about the pro-Italian course outmanoeuvered him by assuming personal command of the armed forces himself ${ }^{189}$. Göring's promotion to Field Marshal was a sop to hide the fact that he had been passed over. The simultaneous promotion of Ribbentrop to Foreign Minister signalled the future limits of Göring's influence over foreign policy.

\section{Ribbentrop}

Ribbentrop's influence, which was feared by all Hitler's audience on 5 November, can be assessed by comparing Hitler's views with the two long reports which Ribbentrop sent from London on 21 May and 28 December 1937. These reports, copies of which he sent direct to Hitler, chart his failure to achieve the aim with which Hitler had sent him to London in August 1936, namely, "Ribbentrop, bringen Sie mir das englische Bündnis! Instead, they develop the opposite policy of building a bloc against Britain ${ }^{190}$.

In his first report at the time of the Coronation, Ribbentrop commented on the use of the Crown as the unifying symbol of the Empire and Britain's determination to bind the Empire closer together by rearmament: "Man wird daher für die nächsten Jahre eher mit einer Stärkung als mit einer Schwächung der Struktur des britischen Imperiums zu rechnen haben." ${ }^{191} \mathrm{He}$ noted the friendliness of the new Prime Minister, Chamberlain, but he did not expect any change in the basic principles of British foreign 
policy. These were the desire "als saturierte Nation « for peace above all, a bad conscience about the treatment of Germany, while Germany's new power, its anti-Russian stand, the problems of Eastern and South-Eastern Europe (which were coming to a head) and its good relations with Italy and Japan made Germany appear a probable aggressor. For its defence, Britain no longer relied on collective security: it would resist attack by Germany on France or Belgium; and although it would not commit itself in the East, the danger existed that it would be drawn into a Russo-German war by its guarantee to France. Ribbentrop hoped that faced with the alternative of a German guarantee of British interests or "nochmaliger Kampf auf Leben und Tod" Britain would make the right choice. However, the Foreign Office still argued that, "Wenn Deutschland in einem russischen Krieg siegreich bliebe, wäre es so stark, daß es mit Europa und dann auch eines Tages mit England machen könne, was ihm beliebe.«The Embassy was making progress in overcoming this attitude but Ribbentrop recommended that »in absehbarer Zeit « Britain should be asked to declare her intentions towards "den deutschen Lebensnotwendigkeiten «. If the result was negative "so ist der Beweis des englischen Einkreisungswillens gegen Deutschland erbracht und man wird dann kompromißlos die notwendigen Konsequenzen ziehen müssen « ${ }^{192}$.

It is noticeable that Ribbentrop talked openly of German conflict with Russia, suggesting that he was responding directly to Hitler's ideas of expansion against the Soviet Union. He was quite candid about German ambitions in his soundings in London. He told Churchill in 1937 that German aims in the East included (in Churchill's words) "Poland and the Danzig Corridor" and that "White Russia and the Ukraine were indispensable«. When Churchill objected that the British Government would not agree to such expansion, Ribbentrop replied: "In that case, war is inevitable. There is no way out. The Fuehrer is resolved. Nothing will stop him and nothing will stop us. ${ }^{193}$

The failure of Ribbentrop's mission in London led him to advocate the alternative policy of building up the Anti-Comintern Pact as a counter-weight to the British Empire. This was the central message of his second, lengthy report drawn up in December 1937. In October, he had won Hitler's support for the extension of the Anti-Comintern Pact to Italy against $A$ uswärtiges $A m t$ resistance. He may have hoped that this would be the spring board for Hitler to confirm a promise that he would become Foreign Minister when Neurath reached the age of 65, at the beginning of February 1938. If so, his strategy appeared in December to have failed, because Hitler was annoyed that he had failed to keep Neurath informed about the extension of the Anti-Comintern Pact. It was under these circumstances that he drew up the December report, which he is alleged to have intended to offer Hitler as his political testament together with his resignation ${ }^{194}$.

In this report ${ }^{195}$, Ribbentrop argued that Britain considered Germany its most dangerous potential opponent, and that it was countering the joint threat of Japan, Italy and Germany by its "gewaltiges Aufrüstungsprogramm « and improving its links with the United States, while at the same time the needs of air defence were tying Britain ever more closely to France ${ }^{196}$. The main question for Britain remained, however, whether it could reach an agreement with Germany to preserve peace and therefore the Empire. Ribbentrop thought there might be members of the Government (though he doubted whether they included Chamberlain or Halifax) who still believed in the possibility of an agreement with Germany along the following lines: return of some German colonies, acceptance of a peaceful $A n s c h l u \beta$ with Austria and improvement of the lot of the Sudeten Germans up to the point of cultural autonomy, in return for Germany accepting non-aggression pacts with its neighbours and limitation on air rearmament on the model of the Anglo-German naval treaty. This, however, was the limit to which those favourably disposed towards Germany would go. Within the political élite, the Foreign 
Office still had a decisive influence with its argument that German force should be opposed by force and its systematic attempts to encircle Germany. Even those who wanted to explore an agreement with Germany were sceptical, but thought it would buy time in which Germany's economic difficulties might force it to greater moderation. Chamberlain had been under pressure from this second group and having failed in his initial policy of dividing Germany, Italy and Japan, he had been forced to agree to Halifax's visit.

Ribbentrop thought there was another important factor: Britain expected that at some time the domestic situation in Czechoslovakia could provoke German intervention there and in Austria, and Britain wanted at all costs to postpone this until its rearmament was further advanced. "Man hört und liest hier oft von 1939, als dem Jahr, in dem England stärker auftreten kann [.. .]《 though Ribbentrop thought that British naval rearmament would take longer ${ }^{197}$. Halifax's remarks about possible changes in the status quo could have been to dissuade Germany from early action by holding out hopes of concessions in the future. Ribbentrop expressed scepticism about the practical results of the Halifax visit: negotiations on colonies would be spun out and used to draw Germany into other issues.

Ribbentrop then posed the crucial question: could the maximum concessions which Chamberlain was likely to offer be reconciled with Germany's minimum demands? Britain and France would offer colonies in return for a German guarantee of Czechoslovakia and arms limitation and possibly Britain would agree to a tolerable solution in Austria. Ribbentrop doubted the wisdom of such an arrangement for Germany, and also mentioned the danger that Britain and France might try to exploit negotiations to cast Germany as the aggressor towards Czechoslovakia. In any case, he did not think that a peaceful solution was possible because, »Territoriale Revision der Tschechoslowakei bedeutet $\mathrm{m}$. E. den Beginn der Auflösung dieses Staatswesens und damit Krieg. « The Czechs would fight rather than allow their state to be broken up; France and Britain might at most force them to concede an autonomous Sudetenland but that would not satisfy Germany, and in any case Ribbentrop did not believe that France and Britain would coerce the Czechs; even with only French backing the Czechs would fight, knowing that a Franco-German war would, in the end, bring Britain in. On 2 January 1938, together with the report, Ribbentrop sent Hitler alone a further note of his conclusions. In this he argued that the only way to prevent French and British intervention against Germany, was to strengthen the combined threat to the British Empire from Japan, Italy and Germany, to the point where Britain was seen to be unable to risk a war in Europe ${ }^{198}$.

The ideas developed by Ribbentrop had no doubt been discussed with Hitler during his frequent visits to Germany (apart from November 1937 to January 1938 when he was out of favour) ${ }^{199}$. They were at one in thinking that no satisfactory agreement could be reached with Britain, unlike the Auswärtiges $A m t$, army command and Göring who still hoped that it might and saw no real alternative. On the other hand, there was an important difference between them over Britain's willingness to resist Germany. Hitler argued that Britain was already gravely weakened and had in all probability written off the Czechs. Ribbentrop, on the other hand, argued that Britain would vigorously defend the Empire and the European balance of power, unless deterred by an anti-British alliance system which might in any case lead to war. Hitler was inclined to ignore Britain and act before the long term balance of rearmament worked against Germany; that is by $1943-45$ at the latest. Ribbentrop wanted to re-orient German policy against Britain, the most dangerous enemy.

Ribbentrop's references to British hopes that economic problems would force Germany to greater moderation, and his argument that British policy was to buy time for 
rearmament, probably reinforced Hitler's desire to act first. Ribbentrop's warning that negotiations might be used to show Germany up as the aggressor may also have influenced Hitler. If Germany were offered limited revision in Eastern Europe and refused it, there was the danger not only of being branded as an aggressor, but equally that Hitler might find himself isolated from the German people as well as the professional élites. Hitler could afford neither the time nor the risk of negotiations.

Hitler did not simply reflect Ribbentrop's views in his statement on 5 November. He agreed with Ribbentrop's anti-British and pro-Italian assumptions, but he added to them his own view of Britain's weakness and the need to exploit Germany's relative strength, which would not outlast 1943-45. To Hitler's audience, however, it must have sounded as though Hitler had adopted Ribbentrop's foreign policy of abandoning Britain and committing himself to the Axis and Japan. Given the conflict immediately before the November meeting over the extension of the Anti-Comintern Pact to Italy, it looked as though Hitler was justifying Ribbentrop's »radical« views. And, despite their differences, Hitler was closer to Ribbentrop than to his other advisers, since Ribbentrop alone among them offered a strategy for expansion by force. The replacement of Neurath by Ribbentrop when the Blomberg-Fritsch crisis broke was the logical sequel.

\section{Conclusion}

Setting Hitler's statement in the context of the views held by his audience, as well as those of Schacht and Ribbentrop, shows the full importance of what he said. The themes he addressed, living space, autarchy, the tactics of expansion, Britain's attitude to negotiations, Britain's capacity to intervene in a European war, the way to exploit Italy's involvement in the Mediterranean, the future changes in the balance of force as other powers rearmed and the timetable for expansion which this indicated, were the themes which most concerned his audience. Hitler's views differed from theirs and also from Ribbentrop's. They dreaded Britain's intervention in a European war and therefore continued to believe in the need for understanding with Britain. Hitler dismissed both the chance of understanding with Britain and the danger of British intervention. This enabled him to answer the vital question of how German expansion could succeed, a question to which the professional diplomats and military leadership had no real answer since they knew that Britain was not likely to agree to the kind of European settlement Germany wanted quickly, if at all, and they also accepted that in time the Empire and its allies (including the United States) would be too strong for Germany. Göring was more optimistic at this stage about reaching agreement with Britain but also saw no viable alternative. Even Ribbentrop believed it would be necessary to establish a German bloc superior to the British Empire before a conflict could be risked. Hitler brushed aside their fears and hopes and supplied his own answer: early expansion by force with lightning speed while Italy and, if possible, France and Britain were involved in the Mediterranean, and in any case before Germany's enemies were ready. The reasons which led Hitler to this conclusion and to the decision to face his audience with it on 5 November were many and varied. But the key was his sense that a crucial opportunity for expansion lay within Germany's grasp. If Germany were to seize the opportunity, however, then rearmament had to be completed on time. At this point Hitler's ideas and the occasion of the meeting on 5 November came together, for the serious deficiencies in the rearmament programme (which prompted the meeting) had to be put right, if Hitler's plans were to be realized.

A further assumption, partly hidden, may also have been important. For Hitler, Czechoslovakia and Austria were simply the first stage: they would constitute the founda- 
tion from which the racial wars for continental and perhaps even world hegemony would be launched. For his audience on 5 November, on the other hand, with the partial exception of Göring, Austria and Czechoslovakia were themselves the crucial goal. Hitler did not dwell on this difference in his statement, but its existence may have made him even more hostile to negotiations. If Chamberlain were to succeed in convincing the German people of Britain's support for their legitimate aspirations, based on selfdetermination, and distinguishing them from Hitler's quest for living space, popular support for Hitler's war would be much harder to achieve.

Other considerations re-enforced Hitler's desire for action : concern about living standards, public opinion and his health. In November, he also finally decided to grasp the nettle of Schacht's resignation because Schacht would not submit to the economic preparations for war which Hitler had authorized Göring to carry out. This made it natural for Hitler to use the 5 November meeting, which arose directly from disputes over the rearmament programme, to clarify his disagreement with Schacht and ensure that he retained the support of his other professional advisers.

For all these reasons, Hitler decided to confront them with a solemn statement, which was prepared in advance and took over two hours to deliver, a statement he described as »das Ergebnis eingehender Überlegungen und der Erfahrungen seiner viereinhalbjährigen Regierungszeit« containing "seine grundlegenden Gedanken über die Entwicklungsmöglichkeiten und -notwendigkeiten unserer außenpolitischen Lage« and he asked that it should be considered as his testament in the event of his death ${ }^{200}$. He may have hoped to win them over, not only by the force of his oratory and the fact that he claimed to have an answer to the problem of German expansion, where they had none, but also through the warning example of Schacht.

His audience was unconvinced and tried in various ways to dissuade him. The Generals prepared new military plans which turned Hitler's assumption that a general European war could be avoided into a condition, thus they hoped postponing action perhaps indefinitely. Neurath tried unsuccessfully to persuade Hitler that what he wanted could be achieved peacefully in time. Göring intensified his pressure on Austria, perhaps to show Hitler that peaceful gains were still possible with British acquiescence and despite Italian objections. Only Raeder accepted the logic of what Hitler said as far as the navy was concerned, and planned as fast as he was able for the capacity to deter Britain from war, or if the worst should happen, for war with Britain.

The objections of his audience did not change Hitler's mind though he did not contradict them directly, apart from his interview with Neurath in January. Instead, and characteristically, the Führer waited for a crisis to enable him to impose his solution. The chance came at the end of January 1938 with the revelations about Blomberg's wife. This was it seems a genuine blow to Hitler who had probably assumed that he could always bend the pliable Blomberg to his will in the last resort ${ }^{201}$. But the conspiracy against Fritsch, Hitler's assumption of command in place of Blomberg, the replacement of Neurath by Ribbentrop, were all signals of a radical course which was confirmed by his renewed commitment to crush Czechoslovakia in 1938. He was not deflected even when he was forced to accept that he had underestimated Britain's willingness to go to war, which required a fresh analysis of how British military power could be excluded from the continent ${ }^{202}$. The 5 November meeting was not the final expression of Hitler's tactics, but he never wavered on the principles - that Germany must expand and take the best chance of expanding without general war. Nor was the 5 November meeting the only occasion on which Hitler expressed views of this kind, as Goebbels' diary shows. Indeed the consistency of the views he expressed to Goebbels and through the mouthpiece of Dietrich with parts of Hoßbach's record is striking. The significance of the 5 November meeting is that on this occasion he tried to impose his views on his 
most senior advisers and was met with scepticism rather than the uncritical adulation to which he was accustomed from party audiences. Hoßbach's record was itself a product of this scepticism. It remains a crucial dividing line in the history of the Führer state.

Appendix A: Hitler, Eden and the Imperial Conference of May 1937. (See above, p. 82-83)

In his address to the Imperial Conference on 19 May, Eden pointed out that Germany was being assisted by Italy's policy of adventure in Abyssinia and Spain which meant that Italy had to give up its interests in Central Europe and no longer appeared to dread the Anscbluß. Eden said that Britain's policy was to make it clear that although she had no military commitments in Central Europe she was nevertheless deeply interested in the outcome of events there (DBFP, Second Series, [see below, fn 61], XVIII, No. 510). Eden tried to obtain Dominions' support for this policy at the Imperial Conference's two subsequent meetings devoted to foreign affairs on 21 May. German domination of Central Europe, said Eden, might have a »very direct bearing on British Imperial interests « because it was possible that after absorbing Austria, Germany would seek an outlet on the Mediterranean at Trieste. "The situation would then [ . . . be one with which the Empire would be most gravely concerned.« But the Dominions representatives disagreed. None of them endorsed Eden's policy; all of them regarded German grievances as just and wanted Britain to make a serious attempt to satisfy those grievances. The Australian Treasurer, Casey, suggested that "Germany should in future be allowed a freer hand in Europe, particularly in regard to the 'Anschluß, with Austria . More explicitly, the South African Prime Minister, Hertzog, warned that if war arose because of Britain's unwillingness to right the wrongs of Versailles or because of Britain's persistence in co-operating with France's Central or Eastern European policy in threatening Germany, then »South Africa could not be expected to have any share or part in such a war «. (Imperial Conference, Second and Third Meetings of Principal Delegates, 21 May 1937, T 9198, 9199/226/387, P. R. O., FO 372/3201.)

Hitler's view that Eden had prevailed at the Conference was clearly wrong and how he came to it is uncertain. He may have accepted the claims of the Paris press, which throughout the week from 17 May insisted that as a result of the talks with Dominions ministers British policy towards Central and Eastern Europe remained identical with French policy. (J. L. Garvin, »Empire and Europe«, The Observer, 23 May 1937, p. 16). From London Ribbentrop reported on 21 May that the foreign affairs part of the conference was

»streng geheim, aber möglicherweise wird man doch manches erfahren können, was Rückschlüsse 1. über die Haltung der Dominien zur bisherigen englischen Außenpolitik und 2. über die zukünftigen englischen Absichten uns gegenüber zuläßt.« (ADAP, C, VI 2 [see below, fn 14], No. 380).

But Ribbentrop does not appear to have followed up this matter in subsequent written reports (perhaps because he did not wish to contradict Hitler, perhaps because his own view of Britain grew increasingly hostile). The French ambassador, Corbin, by contrast, was well-informed and reported to Paris on 4 June: "Visiblement, la menace que la tension des rapports anglo-italiens fait peser sur les communications impériales frappe les représentants d'outre-mer beaucoup plus que la gravité du péril allemand. De là une certaine tendance de leur part à retenir la metropole sur la pente d'engagements trop précis sur le continent, notamment en Europe centrale ou orientale. Cette attitude était prevue, et personne ne s'attendait à voir Ottawa ou Canberra pousser la mère-patrie à defendre la Tchécoslovaquie.« (DDF, Deuxième Série [see below, fn 
132], VI, 22). It is striking that Hitler should have committed himself to a dogmatic and inaccurate conclusion about the conference and one much less favourable to German aspirations than the truth. It suggests that he was determined to back Italy rather than Britain and, was interested only in evidence which would suit his argument. On the Imperial Conference, see also Ritchie Ovendale, Appeasement and the English Speaking World (Cardiff, 1975), pp. 38-51.

Appendix B: Hitler, Spain and war in the Mediterranean. (See above, p. 95).

Hans-Henning Abendroth, Hitler in der spanischen Arena (Paderborn, 1973), pp. 176-78 argues that Hitler's position on 5 November was confused because if general war broke out before Franco won, Franco would very probably be defeated; and secondly because an Anglo-French-Italian war was more likely to arise if Italy remained on the Balearic Islands after the end of the Civil War than during it. Abendroth points out that in fact German policy was not only to keep the Italians on the Balearic Islands (Ribbentrop suggested this to Ciano on 24 October 1937 and Göring to Mussolini on 16 April 1939) and to maintain aid to Franco but also to encourage him to push for an early victory (rather than as Hitler suggested on 5 November seeking to prolong the war). However, to conclude from this (Abendroth p. 179) that Hitler was probably not serious in talking of general war in the Mediterranean in 1938 and that he invented this part of his argument to frighten the Generals into faster rearmament (as Göring claimed) is more questionable. Mussolini may well have persuaded Hitler, during his September visit to Berlin, of the likelihood of war between Italy, France and Britain developing in the near future. The Goebbels diary suggests an inevitable AngloItalian conflict (see above, p. 90); Ribbentrop told the German military attaché in London, Geyr von Schweppenburg, in 1937 that Mussolini in referring to his submarine programme and fortifications on Pantellaria had claimed that in a year's time he would be able to prevent ships moving from the West to the East Mediterranean (Geyr von Schweppenburg to Oberkommando des Heeres, 5. 10. 1937; copy in IfZ [Institut für Zeitgeschichte, München] ED 91, vol. 6); and Fritz Hesse claims that Ribbentrop told him that Hitler had admitted that he had been taken in by Mussolini in September 1937 on the likelihood of early general war in the Mediterranean (Fritz Hesse, Das Vorspiel zum Kriege [see below, fn 128], pp. 81-82). Whatever Hitler's precise calculations about a general war in the Mediterranean and the best way of provoking it may have been, his priority was that Italy should remain preoccupied in the Mediterranean to keep it away from Central Europe. He therefore supported Italian ambitions there and maintained German assistance to Franco even when he would rather have withdrawn German forces for Central Europe (ADAP, D III [see below, fn 14], No. 559).

*We would like to thank Miss Alison Menzies for her expert secretarial help in the preparation of this article.

1 A. J. P. Taylor, "War Origins Again « in: E. M. Robertson ed., The Origins of the Second World War (London, 1971), p. 136. Trial of the Major War Criminals before the International Military Tribunal [IMT] (Nuremberg, 1947), vol. IX, p. 307.

2 See below, pp. 85

3 William Carr, Arms, Autarky and Aggression (London, 1972), pp. 76-77. Timothy W. Mason, Arbeiterklasse und Volksgemeinschaft (Opladen, 1975), pp. 163-64.

4 There is an excellent discussion of this background in Alfred Kube, Pourle mérite und Hakenkreuz. Hermann Göring im Dritten Reich (Munich, 1986), pp. 185-201. See also Jost Dülffer, Weimar, Hitler und die Marine. Reichspolitik und Flottenbau 1920-1939 (Düsseldorf, 1973), p. 447; David Irving, The rise and fall of the Luftwaffe. The Life of Luftwaffe Marshal Erbard Milch (London, 1973), p. 367. 
5 Different approaches to this problem are represented in the symposium, G. Hirschfeld, L. Kettenacker eds., The Fübrer State: Myth and Reality. Studies on the Structure and Politics of the Third Reich (Stuttgart, 1981). On the significance of the Hoßbach Memorandum in terms of Hitler's assertion of his own military strategy, Michael Geyer, "German Strategy in the Age of Machine Warfare, 1914-1945* in: Peter Paret ed., Makers of Modern Strategy from Machiavelli to the Nuclear Age (Princeton, 1986), p. 571.

6 The most ambitious statement of this argument is by Dankwart Kluge, "Das Hoßbacb — ,Protokolls. Die Zerstörung einer Legende." (Leoni am Starnberger See, 1980). This claims to offer »den exakten Beweis« that the document used at Nuremberg was forged. Similar doubts were expressed more cautiously by Goran Henrikson, "Das Nürnberger Dokument 386-PS (das >Hoßbach-Protokollk). Eine Untersuchung seines Wertes als Quelle.« Lund Studies in International History 2 (Stockholm, 1971), pp. 151-94.

7 The history of the document up to 1945 is carefully analysed by Walter Bussmann, "Zur Entstehung und Überlieferung der ,Hoßbach-Niederschrift«", Vierteljabrshefte für Zeitgeschichte. 16. Jg. (1968), pp. 373-84.

8 Bernhard Poll, „Vom Schicksal der deutschen Heeresakten und der amtlichen Kriegsgeschichtsschreibung “, Der Archivar. Mitteilungsblatt für deutsches Archivwesen, 6. Jg. (April 1953), Nr. 2, p. 73. (We are grateful to Dr. Ringsdorf of the Bundesarchiv - Militärarchiv, Freiburg, for this reference.)

9 Viktor von Martin to the Institute für Zeitgeschichte, Munich, January (n. d.) 1954 and enclosures (Institut für Zeitgeschichte [IfZ], Z 535, Martin, Dr. Viktor von, Bd 1); Kluge, Das Hoßbach-»Protokoll (see above, $\mathrm{fn}$ 6), p. 19. Major Thomson reached Westerstede according to his war diary on 15 May (Public Record Office, Kew, London [PRO], WO 171/8038), whereas a copy of the document had already reached the Foreign Office Library by 11 May (see below).

10 Murphy to the Secretary of State, 25 May 1945 (National Archives Washington [NA], Diplomatic Branch, State Department, United States Political Adviser for Germany. \# 415, 840.414/5-2545). Bradley F. Smith, Reaching Judgment at Nuremberg (London, 1977), p. 141. Kluge, Das Hoßbach-»Protokoll $\ll$ (see above, fn 6), p. 46 argues that a microfilm was used in order to conceal the forgery. The use of microfilm was not, however, a unique procedure adopted for the Hoßbach memorandum. In a meeting of representatives of the British and American prosecution teams in London on 24 October 1945, it was noted that the Foreign Office had photostats of a number of documents smade from micro-film of the originals sent to London by a joint British-American micro-film unit«. The originals were described as being "in American hands in Germany» (PRO, FO 1019/90).

11 This file now in the Imperial War Museum, London, came from the Historical Section of the Cabinet Office, where it was classified in the Enemy Documents Section, as AL 2662. It is entitled "Copy of the sHoßbach Minutes of a Conference in the Reich Chancellery Berlin of Hitler \& his leading Generals, 5 November 1937 16.15-20.30 hrs. (See also P. I. D. [Political Intelligence Department] Report No. 154) (Ex. F. O. Library 1960) (duplicates available)«. It also carries the number $\mathrm{E} 187$ and $(\mathrm{Ph})$ [Photocopies]. It appears therefore to have been the Foreign Office Library file for the Hoßbach memorandum. The P. I. D. report contains simply a synopsis of the memorandum and the German text. (We are grateful to Dr John P. Fox of the German Documents Section of the Foreign and Commonwealth Office for this last piece of information.)

12 Kluge, Das Hoßbach-»Protokoll « (see above, fn 6), p. 31, Henrikson, "Das Nürnberger Dokument 386-PS « (see above, fn 6), p. 165. The most likely explanation for their error is that Kirchbach's signature did not show up in the photostatic copy from the National Archives which they used.

13 The State Department copy has two marginal notations: on page 3 nEinsatz « has been suggested for "Ansatz « in the text and on page 6 "Macht? « has been suggested instead of "Mit in "Mitzuwachs" in the text. Clearly the reader thought in both cases that his suggestions would make better sense than the original. The Foreign Office copy has a number of marginal lines, presumably indicating passages the reader thought of particular interest.

14 IMT, XXV (see above, fn 1), pp. 402-413. Akten zur Deutschen Auswärtigen Politik 1918-1945 [ADAP], Serie D, (Baden-Baden, 1950-1970), Bde 1-13, Bd 1, No. 19, pp. 25-32.

15 IMT, XXV (see above, fn 1), p. 413; ADAP, D I (see above, fn 14), p. 32 . One translation in the Foreign Office file has "?Kinzbach (?Kinzlach)«. The Washington Office of the American prosecution team were also not able to decipher the signature on the State Department copy, see below, p. 116. It was correctly identified, however, in a translation used by the staff of the prosecution team in Nuremberg, and certified correct by E. Glazier on 14 November 1945 (see below, fn 23.) It is not clear why this was overlooked in the published versions.

16 Eugene C. Gerhart, America's Advocate: Robert H. Jackson (New York, 1958), pp. 311-12, 335; Smith, Reaching Judgment at Nuremberg (see above, fn 10), pp. 41-42.

17 Gerhart, America's Advocate (see above, fn 16), p. 333.

18 Nazi Conspiracy and Aggression [NCA] (Washington, 1946), vol. I, p. xiv. (Also Telford Taylor, „The use of captured German and related records in the Nürnberg War Crimes Trials«, in Robert Wolfe ed., Captured German and Related Records. A National Archives Conference (Ohio, 1974), p. 95. 
19 NA, Modern Military Branch, United States Chief of Counsel for the Prosecution of Axis Criminality, RG 238, Nuremberg Staff Analysis for Doc. 386.-PS. Copy of the communication of the Acting Assistant Chief of Sraff G2 on OSS activities in Germany, dated 8 May 1945 (PRO WO 171/29). On X-2, see the published version of the official, War Department, War Report of the OSS, (New York, 1976), vol. 1, pp. 188-98. We are grateful to the following former intelligence officers of 21 Army Group for their help in answering questions about the possible routes the document may have followed: Dr A. J. Krailsheimer, Dr J. S. G. Simmons, Sir Edgar Williams and Colonel Peter Earle. We are also grateful to Professor Michael Balfour, at that time in the Intelligence Section of the Psychological Warfare Division of SHAEF, for explaining the ways in which the document may have been communicated from SHAEF to the Foreign Office.

20 Griggs to Wendelin, 11 September 1945, enclosing a telegram from Kaplan (but signed Jackson) to Griggs, dated 7 September 1945 (NA, Diplomatic Branch, State Department, 740.00116 EW Prosecution/9-1145). (Smith, Reacbing Judgment at Nuremberg (see above, fn 10), p. 141, states erroneously that the telegram came from Nuremberg.) A copy of the summary is in NA, ibid.,/6-2545. It was sent to Jackson by Colonel Telford Taylor on 25 June 1945, Smith, Reaching Judgment at Nuremberg (see above, fn 10), p. 322, fn. 94. (We have been unable to locate this reference.)

21 Smith, Reacbing Judgment at Nuremberg, (see above, fn 10), p. 142; Kluge, Das Hoßbach-»Protokoll (see above, fn 6), pp. 141-42.

22 The document analysis section of the London office did not move to Nuremberg until 10 September. The decision is recorded in the minutes of a meeting on 4 September in a file entitled "Minutes of meetings of Chief Prosecutors and Committees (PRO, FO 1019/86). We have not been able to discover when the Paris office moved to Nuremberg and therefore cannot say whether Weldon drew up his report in Paris or Nuremberg.

23 A reason for thinking that they were working from a transcript not a photocopy is that Weldon made no reference to Kirchbach's certification, referring only to Hoßbach as a possible lead for further evidence. The English translation of 386-PS, attached to Weldon's report, does carry Kirchbach's certification and identifies him correctly but this may have been attached to Weldon's report later, perhaps replacing the document he worked from, since the translation is itself certified by E. Glazier with the date 14 November 1945 (whereas Weldon's report is dated 1 September). Interestingly, one of the English translations in the Foreign Office file (headed "Annex A«) does not carry any reference to Kirchbach's certification, and ends with Hoßbach's name. Weldon may therefore have been using that, or a similar, translation and transcript. (Smith, Reacbing Judgment at Nuremberg (see above, fn 10), p. 141, assumes that the prosecution team only had the summary from the Washington Office until they asked for the State Department document on 7 September. This could only apply to the London office, however, since Weldon's report is dated 1 September and clearly refers to a complete document from OSS, not a summary.)

24 Smith, Reaching Judgment at Nuremberg (see above, fn 10), p. 142.

25 Viktor von Martin to IfZ, Jan. 1954 (IfZ, Z 535, Bd 1); declaration by von Kirchbach in Deutsche Opposition, 2. Jg., Nr. 13, (27 March 1952), copy in Bundesarchiv - Militärarchiv [BA-MA] N 24 (Nachlaß Hoßbach) File No. 72; Bussmann, "Zur Entstehung (see above, fn 7), pp. 379-81.

26 Cf. Smith, Reacbing Judgment at Nuremberg (see above, fn 10), p. 142. The SHAEF G-2 files have been declassified since Smith's book (1977) but a check of appropriate folders kindly undertaken for the present authors by staff of the National Archives revealed no evidence of the Hoßbach memorandum and no mention of it. The files of X-2, OSS are in process of being transferred from the CIA to the National Archives. Again, no information about the Hoßbach memorandum has been found in those received so far. (We are grateful to Mr Wilbert Mahoney of the National Archives for his assistance.) If the original was sent to the War Office in London, it may still be in the files of one of the intelligence sections which are closed to research. There is an illuminating description of arrangements for the handling of documents and of the confusion caused by the competition of different agencies at the end of the war in an official account of the Military Intelligence Research Section (PRO, WO 208/3237). The Imperial War Museum contains a negative print (white on black) of Kirchbach's copy among its Nuremberg trial papers (FO 645, Box 181). Some words on this print are difficult to read and they correspond to notes about uncertain readings on a transcript of the memorandum in the Foreign Office file, suggesting that this document may have been used first before the positive print (black on white) was received from SHAEF (AL 2662). We are grateful to $\mathrm{Mr} \mathrm{K.} \mathrm{H.} \mathrm{M.} \mathrm{Duke,} \mathrm{formerly} \mathrm{a} \mathrm{member} \mathrm{of} \mathrm{the} \mathrm{British} \mathrm{War} \mathrm{Crimes} \mathrm{Executive} \mathrm{and} \mathrm{of}$ the editorial team of Documents on German Foreign Policy, for pointing out that the negative print was probably the first stage in the photographic copying process.

27 A partial explanation for the omission of any reference to the source of the document may be the very early date at which it came into Allied hands. The Field Branch of the Documentation Division of the American Prosecution team which kept systematic records of source and acquisition of other documents was only set up in July 1945. See the affidavit of Major William H. Coogan, dated 19 November 1945, on the procedures adopted for processing the documents for the trials in NCA, vol. III (see above, fn 18), pp. 1-4. 
commented on by Henrikson, "Das Nürnberger Dokument« (see above, fn 6), pp. 169-70, 177-78.

29 NCA, vol. I (see above, fn 18), p. XIII; Documents on German Foreign Policy 1918-1945 [DGFP], Series D, Vol. I, p. 29.

30 Imperial War Museum, AL 2662; NCA, vol. III, (see above, fn 18), pp. 295-305. Using Henrikson's analysis of the divergences, the NCA version corresponds to Annex A except for his (Henrikson's) reference No, 5 (Henrikson, »Das Nürnberger Dokument« [see above, fn 6], pp. 177-78).

31 Using Henrikson's analysis, the IMT English version corresponds to »Glazier« except for Henrikson's Nos. 3, 6 and 8 and the Trials of the War Criminals version corresponds to "Glazier" except for Nos. 1 and 7 (ibid., pp. 177-78).

32 IMT, II (see above, fn 1), p. 273. Alderman himself noted as he read out the document that the translation did not appear to make sense in two places, one of which did indeed result from faulty translation caused by the omission of another line of the German text. Ibid., pp. 263, 272. The line in question is missing from both "Annex A « and "Glazier « suggesting that either one influenced the other or that they were both influenced by a common parent. There is nothing suspicious about this omission: it simply made nonsense of the passage in both IMT (English version) and NCA - See Henrikson's Reference No. 7 (Henrikson, „Das Nürnberger Dokument火 [see above, fn 6], PP. 177-78)

33 Friedrich Hoßbach, Zwischen Webrmacht und Hitler 1934-1938 (Wolfenbüttel and Hannover, 1949), Pp. 9, 124-36. A second edition without significant alterations was published in Göttingen in 1965. Page references in this article are to the first edition which is compared with earlier drafts.

34 Ibid., pp. 152-54, 157.

35 Ibid., pp. 217-220, »Die Entstehungsgeschichte der Niederschrift vom 10 November 1937 «; Henrikson, "Das Nürnberger Dokument« (see above, fn 6), p. 173.

36 In a statement on 29 November 1945 Hoßbach explained his motives in this way: "Die Niederschrift habe ich nicht auf Befehl, sondern aus eigenem Antrieb verfaßt, weil mir die politischen Ausfiuhrungen Hitlers von folgenschwerer Bedeutung zu sein schienen. Aus diesem Grunde hatte ich auch dem General Beck [...] das ,Protokolk zur Einblicknahme ausgehändigt. (BA-MA, N 24/71). He also showed it to his fellow Adjutants (von Below from the Luftwaffe and von Puttkamer from the navy). According to Kluge, they both thought in the 1970's that the text of Hitler's statement in the Nuremberg document differed from the one shown them by Hoßbach. Von Below thought the original was shorter than the version used at Nuremberg and contained nothing sensational. These self-serving memories carry no weight, however. There is independent confirmation of the text of Hitler's statement in the commentary written by Beck which follows Hoßbach's original very closely, though he does not comment on everything Hitler said. There is further independent confirmation in the language of the amendment, dated 7 December 1937, to the existing military plans. Kluge, Das Hoßbach-»Protokoll (see above, fn 6), pp. 35-36. Cf. Nicolaus v. Below, Als Hitlers Adjutant 1937-45 (Mainz, 1980), Pp. 48-50. Klaus-Jürgen Müller, General Ludwig Beck. Studien und Dokumente zur politisch-militärischen Vorstellungswelt und Tätigkeit des Generalstabschefs des deutschen Heeres 1933-1938 (Boppard am Rhein, 1980), pp. 239-43, 254-66, 493-501.

37 For the opposite view see Kluge, Das Hoßbach-»Protokoll (see above, fn 6), pp. 105-13. It is also worth noting that no link has been established between the copies referred to by opposition groups in 1938 and the Nuremberg copy which bore Kirchbach's signature and which cannot therefore be earlier than 1943.

38 Hoßbach, Zwischen Webrmacht und Hitler (see above, fn 33), pp. 5-7, 187.

39 BA-MA, N 24/97, pp. 82-3, date on p. 73.

40 Ibid. In another reference to the 5 November meeting in a draft of a different part of the memoir, Hoßbach wrote that the question of Austria had played no part in the calculations of military leaders before February 1938, although Hitler had made a single veiled allusion to Austria to him around Christmas 1937 and, he went on, "Allerdings hatte schon vorher am 5. 11. 1937 eine Sitzung [...] in der Reichskanzlei im Beisein von Blomberg, Fritsch, Raeder, Göring und vielleicht auch Neurath stattgefunden, in der der Führer sein politisches Vermächtnis vorgetragen hatte, das sich mit den Möglichkeiten einer späteren Einverleibung der Tschechei und Österreichs befaßte.« Hoßbach added that Hitler did not return to the subject and that the army command made no preparations for war as a result before January 1938 but that, on the contrary, relations between Hitler and the army became noticeably strained at that time. In a later footnote to this passage Hoßbach added, "Dieser Absatz ist am 4. Mai 1945 geschrieben worden. Mehr war mir über die Sitzung vom 5. 11. 1937 im Augenblick des Niederschreibens nicht mehr in Erinnerung. Erst nachdem ich das veröffentlichte ,Hoßbach Protokoll vom 10.11.1937، im Winter 1945/46 zu Gesicht bekam, fielen mir weitere Einzelheiten seiner Entstehung wieder ein.« (BA-MA, N 24/23.)

41 Hoßbach, Zwischen Webrmacht und Hitler (see above, fn 33), pp. 187-88. The source of the German text published in Die Wandlung ed. Dolf Sternberger, Jg. 1. Heft 4 (April 1946), pp. 354-65 is unknown. Hoßbach suggested that it was probably a duplicated copy of Kirchbach's copy; note by Hoßbach, "Ein Beitrag zur Wahrheit«, 23. 9. 1946 (BA-MA N 24/98). It seems more likely that the text was obtained from a source at the Nuremberg trials. The printed text contains some discrepancies from the IMT German version, including the omission of 2 lines, presumably due to imperfect transcription. 
42 Hoßbach, Zwischen Webrmacht und Hitler (see above, fn 33), p. 187. Hoßbach noted that the idea of the influence of Mussolini's visit first occurred to him on 20 Dec. 1946, the day he wrote about it (BA-MA, N 24/98).

43 Ibid., Pp. 137-39.

44 Ibid., pp. 180-82, quotation on p. 182.

45 Ibid., pp. 191-93, quotation on p. 191.

46 Ibid., p. 145.

47 Müller, General Ludwig Beck (see above, fn 36), pp. 242-44, 249-65.

48 Müller points out that the new military plans drawn up after the 5 November 1937 meeting, and approved by Hitler, included the conditions to which the Generals attached such importance. He concludes that both Beck and Fritsch decided that Hitler was not after all serious about attacking Czechoslovakia in 1938; ibid., pp. 261-66.

49 It is consistent with this bias that Hoßbach alleges that there were no offensive military preparations against Austria and Czechoslovakia before the Fritsch crisis, which is misleading; Hoßbach, Zwischen Webrmacht und Hitler (see above, fn 33), pp. 191-93 and above, fn 40, cf. on the military plans in 1937, Müller General Ludwig Beck (see above, fn 36), pp. 225-72.

50 Hoßbach, Zwischen Webrmacht und Hitler (see above, fn 33), p. 219; ADAP, D, I, No. 19 (see above, fn 14), p. 32.

51 Harold C. Deutsch, Hitler and His Generals. The Hidden Crisis January - June 1938 (Minneapolis and London, 1974), pp. 59-77, cf. Hermann Gackenholz, „Reichskanzlei, 5. November 1937. Bemerkungen über >Politik und Kriegsführung، im Dritten Reich« in Richard Dietrich, Gerhard Oestreich eds., Forscbungen zu Staat und Verfassung. Festgabe für Fritz Hartung (Berlin, 1958), Pp. 470-84.

52 Gerhard L. Weinberg, The foreign policy of Hitler's Germany. Starting World War II 1937-1939 (Chicago and London, 1980), pp. 261-464; Kube, Pour le mérite (see above, fn 4), pp. 236-49.

53 H. W. Koch, wHitler and the Origins of the Second World War: Second Thoughts on the Status of Some of the Documents in Robertson, Origins (see above, fn 1), p. 168. Cf. H. W. Koch, „Hitler's ,Programmer and the Genesis of Operation sBarbarossars in H. W. Koch ed., Aspects of the Third Reich (London, 1985), pp. 285-322.

54 ADAP, D, I, No. 19 (see above, fn 14), pp. 29-30. Weinberg, Starting World War II (see above, fn 52), pp. 36-37. J. Thies, Architekt der Weltherrschaft. Die »Endziele» Hitlers (Düsseldorf, 1976), pp. 110-19.

55 Cf. E. M. Robertson, Hitler's pre-war policy and military plans 1933-1939 (London, 1963), p. 99; Müller, General Ludwig Beck (see above, fn 36), pp. 246-47.

56 Gerhard Meinck, Hitler und die deutsche Aufrüstung 1933-1937 (Wiesbaden, 1959), pp. 179-81; cf. ADAP, D, I, No. 19 (see above, fn 14), p. 29.

57 ADAP, D, I, No. 19 (see above, fn 14), pp. 27-29.

58 This reads like a reference to the Statute of Westminster 1931 under which the sovereignty of the Imperial Parliament over the Dominions ceased and only the Crown remained in law as a symbolic link. It is more likely, however, that Hitler had in mind the recent Imperial Conference of May 1937 timed to coincide with the coronation of George VI. Cf. Ribbentrop's report on the coronation of 21. 5. 1937, below, p. 103.

59 ADAP, D, I, No. 19 (see above, fn 14), p. 30. Hitler may have been influenced by a report he had received from the leader of the Sudeten Germans, Konrad Henlein, on 17-18 October 1937 on a visit paid by Henlein to London, where he had formed the impression that neither Britain nor France would intervene in favour of the Czechs. Robertson, Hitler's pre-war policy (see above, fn 55), pp. 104-106.

60 Axel Kuhn, Hitlers außenpolitisches Programm (Stuttgart, 1970), pp. 70-123, 178-219; Josef Henke, England in Hitler's politischem Kalkiul (Boppard am Rhein, 1973), pp. 35-107; Oswald Hauser, England und das Dritte Reich. Zweiter Band 1936 bis 1938 (Göttingen and Zürich, 1982).

61 Documents on British Foreign Policy 1919-1939 (DBFP) (London 1947 ff.), Second Series, vol. XIX, Nos. 264, 283, 294, 298; Sir N. Henderson to Lord Halifax, 4. Nov. 1937; PRO, FO $800 / 268$. Halifax planned originally to visit Berlin, ostensibly to see the International Sporting Exhibition, from 8-10 November. The dates were postponed, however, to 17-21 November to enable him to meet Hitler. DBFB, Second Series, XIX, Nos. 261, 294, 303, 306, and Halifax's report of his visit and conversations, No. 336.

62 See, for instance, Hauser, England und das Dritte Reich (see above, fn 60), 2, pp. 42-254.

63 For a short description of the provenance and form of the great bulk of the texts of the Goebbels' diaries, which only became available for research in 1981, see Martin Broszat, „Goebbels Tagebücher« in Vierteljabrshefte für Zeitgeschicbte, 29. Jg. (1981), Pp. 124-25. For a brief discussion of the value of this remarkable source, see Hans Günter Hockerts, "Die Goebbels-Tagebücher 1932-1941. Eine neue Hauptquelle zur Erforschung der nationalsozialistischen Kirchenpolitik.«, in Dieter Albrecht et al. eds., Politik und Konfession (Berlin, 1983), pp. 359-63. References below are taken from the typescript version of the diaries which was consulted in the Bundesarchiv (BA), Koblenz, in 1982. In cases of doubt about the transcription, the quotations were checked against the manuscript version which was also available on photocopy but which is barely legible. The Bundesarchiv reference for the typescript version for 1935 is NL 118/62;1936, Ibid.63;1937, Ibid. 64; 
1938, Ibid., 65. References below will be given by the date of the diary entry. Because of copyright restrictions it is not possible to give quotations from the diaries.

64 On the disarmament negotiations, Survey of Intemational Affairs 1935, vol. I, ed. by A. J. Toynbee (London, 1936), pp. 57-8. The annual Survey of Intemational Affairs ed. by A.J. Toynbee for the years 1935-1937 (London 1936-1938) will be citied subsequently simply as Survey 1935, 1936, 1937.

65 Entry for 9.6.1936 (Goebbels generally wrote up his diary a day after the events he recorded). As Dr. Hockerts points out, the Goebbels diaries provide no support for the view that Hitler's talk of expansion East was not meant literally but as a metaphorical and utopian expression; for this view see Martin Broszat, "Soziale Motivation und Führer-Bindung des Nationalsozialismus«, Vierteljabrshefte fuir Zeitgeschichte, 18. Jg. (1970), pp. 406-49, and the criticisms of Klaus Hildebrand, "Hitlers Ort in der Geschichte des preußisch-deutschen Nationalstaates«, Historische Zeitschrift, Bd 217 (1973), pp. 598-600; Hockerts, "Die Goebbels-Tagebücher (see above, fn 63), p.362. For a perceptive discussion of this problem in the light of Hitler's policy in Spain, see Wolfgang Schieder, "Spanischer Bürgerkrieg und Vierjahresplan« in Wolfgang Michalka, Nationalsozialistische Außenpolitik (Darmstadt, 1978), 326-330.

66 Entry for 23. 9.1935. Cf. Jens Petersen, Hitler-Mussolini. Die Entstebung der Achse Berlin-Rom 1933-1936 (Tübingen, 1973), pp. 361-66.

67 Entry for 19. 10.1935; see also entries for 13. and 17. 10. 1935.

68 Goebbels was probably referring to Italian proposals for negotiations on the basis of the military position presented to the relevant League of Nations' Committee on 15 April 1936; Survey 1935, vol. II (see above, fn 64), pp. 347-48.

69 Entries for 9. 5., 10.5., and 11.5. 36. On the British "questionnaire " which followed the German remilitarization of the Rhineland, see Survey 1936 (see above, fn 64), pp. 335-44.

70 These reflections were stimulated by a meeting Hitler had with the Italian Minister of Propaganda, Alfieri; entry for 5. 10.1936.

71 The pact was signed on 25 November. The Italian annexation of Abyssinia was recognized on 24 October and the Spanish National Government was recognized on 18 November but Manchukuo, after resistance from the Auswärtiges $A m t$, not until 12 May 1938 when Ribbentrop had become Foreign Minister; on the last, John P. Fox, Germany and the Far Eastem Crisis 1931-1938 (Oxford, 1982), pp. 175-317.

72 Hitler had raised Germany's demand for colonies in his speech to the Nuremberg party rally on 9 September 1936; Survey 1936 (see above, fn 64), p. 240.

73 In his conversation with Ciano on 24 October 1936, Hitler expressed many of the views which were to determine his policy in 1937 . He said British policy was designed to divide Germany and Italy in order to attack them separately and suggested that they should go over to the offensive, the Mediterranean being an Italian sea whereas Germany must have liberty of action in the East and the Baltic. Italy and Germany, Hitler described as the "natural enemies of Britain »the conservative power". Hitler also predicted that German rearmament would be ready in three years, more than ready in four and better still in five. Ciano's Diplomatic Papers ed. Malcolm Muggeridge (London, 1948), pp. 56-60. Cf. Petersen, Hitler-Mussolini (see above, fn 66), Pp. 490-92; Gerhard L. Weinberg, The Foreign Policy of Hitler's Germany. Diplomatic Revolution in Europe 1933-1936 (Chicago and London, 1970), pp. 336-37.

74 Entry for 15. 11.1936 and cf. entry for 10.4.1937.

75 Entry for 15. 1.1937.

76 Entries for 15. 11. and 2. 12.1936.

77 Entry for 28. 1. 1937. On German relations with Poland, Yugoslavia and Rumania, Weinberg, Starting World War II (see above, fn 52), pp. 193-96, 215-220, 233-35. Cf. Göring's conversations with Group Captain Christie in 1937, below p. 102.

78 Entry for 23. 2. 1937.

79 Entry for 13. 3. 1937; cf. Hockerts "Die Goebbels-Tagebücher" (see above, fn 63), pp. 371-81.

80 Entry for 15. 3. 1937. Cf. Weinberg, Starting World War II (see above, fn 52), p. 273 and Papen's memorandum of his oral report to the Führer on 13 March 1937. Papen (German ambassador to Vienna) discussed the Austrian situation and British policy towards the Axis. He recommended strengthening the Axis in order to extract the best terms from Britain; ADAP, D, I (see above, fn 14), No. 216.

81 Entries for 21. 1., 4. 3., 27. 3., 25.6. 1937.

82 Entries for 4.4., 3.5. 1937. For the background, R. J. Moore, The Crisis of Indian Unity 1917-1940 (Oxford, 1974), PP. 292-317 and F. S. Lyons, Ireland since the Famine (London, 1971), pp. 531-33.

83 Entry for 5. 12. 1936. Edward VIII was considered pro-German and his abdication was seen as a defeat. Joachim von Ribbentrop, Zwischen London und Moskau (Leoni am Starnberger See, 1953), pp. 91, 101-105. As Duke of Windsor, he visited Germany in October 1937. Goebbels noted the care which Hitler took over the visit (entry for 6. 10.1937) and after meeting the Duke he recorded his good impression and his feeling that an alliance with Britain would have been easier but for the abdication (entry for 12.10.1937). Cf. Henke, England in Hitlers politischem Kalkül (see above, fn 60), pp. 65-69.

84 Entry for 12. 5. 1937. 
85 Entries for 1. 4., 9. 7. 1937. Goebbels' latter reference is to the report of the Royal Commission under Lord Peel which recommended the partition of Palestine into an Arab state, a Jewish state and a British mandate for Jerusalem and Bethlehem with a corridor to the sea; A. J. P. Taylor, English History 1914-1945 (Oxford, 1965), p. 407. On the varying reactions this provoked from Nazi party and German Government agencies, Lukasz Hirszowicz, The Third Reich and the Arab East (London, Toronto, 1966), pp. 20-42.

86 Entries for 18. 2. and 20. 2. 1937.

87 Entries for 7. 2., 3. 3., 6. 3., 13. 4., 17. 5. and 26. 5. 1937. Michalka's argument, based on Foreign Office records, that in 1936-37 Goebbels was anti-British and favoured an arrangement with the Soviet Union (Wolfgang Michalka, Ribbentrop und die deutsche Weltpolitik 1933-1940. Außenpolitische Konzeptionen und Entscheidungsprozesse im 3. Reich [München 1980], pp. 213-14) clearly needs revision in the light of Goebbels diary. Goebbels told Hitler of criticisms of Ribbentrop's conduct in London on 26 May and he was preparing to speak to Hitler about Ribbentrop again in October-November (entries for 27.10. and 16.11.). However, the Deutscbland and Leipzig incidents in May-June and the Halifax visit in November on both occasions hardened Hitler's attitude towards Britain. During the February 1938 crisis Goebbels finally told Hitler that he thought Ribbentrop a flop but this did not prevent Hitler making him Foreign Minister; entry for 1. 2. 1938.

83 Entry for 31.5. 1937.

89 A committee of the powers, including France, Britain, Italy, Germany, Portugal and the Soviet Union, who had agreed to a policy of non-intervention in Spain. Survey 1937 (see above, fn 64), vol. II, PP. 313-14.

90 Entries for 31. 5.-3.6. 1937.

91 Entry for 20.6. 1937. Survey 1937, vol. II (see above, fn 64), p. 315-18. To persuade Germany to return to the Non-Intervention Committee, it had been accepted that if a similar incident should recur, the united fleets of the four powers involved in patrolling the Spanish coast for the Committee, France, Britain, Germany and Italy, should consider common action. Ibid.

92 Entries for 22-25.6.1937; cf. Survey 1937 (see above, fn 64), vol. II, p. 319.

93 Entries for 25. 6., 27.6., 30.6. 1937. On the Mackenzie King visit, Weinberg, Starting World War $I I$ (see above, fn 52), pp. 16, 111.

94 Entries for 1.7., 3. 7., 6.7., 10.7.1937.

95 Entry for 13.7. 1937. Goebbels records that among those present were Papen, Wilhelm Keppler (whom Hitler had put in charge of Nazi party affairs concerning Austria; Weinberg, Starting World War II [see above, fn 52], p. 278), Todt (who was in charge of the construction programme) and Kerrl (the Minister of church affairs). Hoßbach gives a picture of these lunch-time conversations, mentioning that Goebbels was usually there, and that Hitler liked to see him to enliven the conversation. The rest of the company would consist of other state and party leaders, often including Göring and Himmler, and occasionally people from further afield; Hoßbach, Zwischen Webrmacht und Hitler (see above, fn 33), Pp. 26-27. Hitler had expressed very similar sentiments about Britain at a lunch with the German military attachés in December 1936; Freiherr Geyr von Schweppenburg, Erinnerungen eines Militärattachés. London 1933-1937(Stuttgar, 1949), pp. 100-101.

96 Entries for 15-18.7., 23-25.7., 31.7.-1. 8. 1937; cf. Survey 1937, vol. II (see above, fn 64), pp. 331-39.

97 Entries for 31. 7., 1. 8., 3. 8., 25-26. 8. 1937.

98 Entries for 3-4.8., 6. 8., 22. 8., 10. 10. and 19. 10. 1937; cf. Survey 1937, vol. I (see above, fn 64), pp. 329-32.

99 Entry for 3. 8. 1937. Hitler again talked of using force against Austria on 13 September; entry for 14. 9. 1937. On German sbullying of Austria in August and September 1937, Weinberg, Starting World War II (see above, fn 52), p. 279. The reference to Hungary was probably prompted by the temporary rapprochement between Hungary and the Little Entente countries in the Summer of 1937; Thomas L. Sakmyster, Hungary, the Great Powers, and the Danubian Crisis 1936-1939 (University of Georgia Press, Athens, 1980), pp. 91-96. On German policy in the Sino-Japanese War, Fox, Germany and the Far Eastern Crisis (see above, fn 71), pp. 229-290.

100 Entry for 8. 9.1937.

101 Entries for 28. 9., 29. 9. 1937. Goebbels' language which assumed an absolute breach between Italy and Britain probably reflected the hardening of fronts in the Mediterranean at the beginning of September which led up to the Nyon Conference; Survey 1937 (see above, fn 64), vol. II, pp. 339-52.

102 On Schacht, entries for 2-4. 11. 1937 (cf. entries for 12. and 14. 8. 1937). Kube, Pour le mérite (see above, fn 4), pp. 191-96. On the armed forces, entries for 8. 9., 10-11. 10 (where Goebbels noted that Hoßbach was acquiring too much influence over the Führer) and 28. 10. 1937. Hoßbach refers to the party's suspicions towards the army and himself, Zwischen Webrmacht und Hitler (see above, fn 33), pp. 33-34, 137-39. The Luftwaffe adjutant, Nicolaus v. Below, also noted the tensions between Göring and Blomberg, Göring's dislike of Hoßbach whom he saw as an opponent of Hitler, and the equal dislike of the Generals for the "Amateursoldaten « of the Luftwaffe with Göring and his State Secretary, Milch, first and foremost; Below, Als Hitlers Adjutant (see above, fn 36), p. 37. There can be little doubt that Göring was jealous of Blomberg and ambitious to succeed him; Deutsch, Hitler and His Generals (see above, fn 51), p. 87; Kube, Pour le mérite (see above, fn 4), 
pp. 197-98. R. J. Overy, Goering. The "Iron Man" (London, 1984), pp. 69-70; Stefan Martens, Hermann Göring. "Erster Paladin des Fübrers» und "Zweiter Mann im Reich (Paderborn, 1985), pp. 128-31. It is in character that having disposed of Blomberg and Fritsch in February 1938, he at once began to intrigue against the only surviving service chief, Raeder, telling Goebbels that Raeder was also opposed to the party; entry for 6. 2.1938.

103 Entry for 6. 11. 1937. On the colonial question, Klaus Hildebrand, Vom Reich zum Weltreich. Hitler, NSDAP und Koloniale Frage 1919-1945 (Munich, 1969), pp. 522-23. Hildebrand (ibid., p. 520) suggests that Eden's speech in the House of Commons on 1 November, in which he attacked Mussolini and, by implication, Germany may have contributed to Hitler's anti-British mood at the time of the 5 November meeting.

104 Entries for 17. 11., 26. 11., 27. 11. 1937. Cf. Halifax's record of his discussion with Hitler, DBFP, Second Series, XIX, No. 336, the German record in ADAP, D, I (see above, fn 14), No. 31 and the account by the German interpreter, Paul Schmidt, Statist auf diplomatiscber Bübne 1923-45 (Bonn, 1953), pp. 384-86.

105 Entry for 2. 12. 1937. Goebbels was referring to the visit of the French Premier and Foreign Minister, Chautemps and Delbos, to London which followed Halifax's return from Berlin. Survey 1937, vol. I (see above, fn 64), p. 340 and Weinberg, Starting World War II (see above, fn 52), pp. 123-26.

106 Entries for 26. 1.-6. 2. 38 .

107 Georg Dertinger (1902-1968), chief editor of Dienatag until 1934, chief editor of the news service "Dienst aus Deutschland $1934-45$, General Secretary of the C.D.U. in the Soviet zone 1946-1949, Foreign Minister of the G. D. R. 1949-53, imprisoned 1953 and sentenced to 15 years in 1954 ostensibly for passing information to Western intelligence services, released 1964. HansJoachim Kausch (1907-1974), Berlin correspondent of the Hamburger Nachricbten and Schlesische Zeitung 1931-44 and chief editor of Dienatag from 1934 until it ceased operating in 1944, chief editor of the Bonn and Berlin offices of Die Welt 1946-1950.

108 BA, ZSg. 101, Sammlung Brammer. For an analysis of this source for the period from February 1938 to September 1939, Hans Booms, "Der Ursprung des Zweiten Weltkrieges - Revision oder Expansion in Geschichte in Wissenschaft und Unterricht Jg. 16, Heft 6 (Juni 1965), pp. 329-53, reprinted in Gottfried Niedhart, Kriegsbeginn 1939. Entfesselung oder Ausbrucb des Zweiten Weltkrieges?(Darmstadt, 1976), pp. 52-93.

109 BA, ZSg. 101/30: Informationsbericht No. 57, 5. 1. 1937, No. 58, 7. 1. 1937, a loose page numbered 37, also Informationsbericht No.61, 22. 1. 1937 and No. 62, 27. 1. 1937.

110 Ibid. Informationsbericht No. 75, 24. 3. 1937, No. 84, 19.4. 1937. On the Auswärtiges Amt and the economic aspects of Germany's involvement in Spain, Glenn T. Harper, German Economic Policy in Spain during the Spanish Civil War 1936-1939 (The Hague, Paris, 1967), pp. 29-51.

111 Ibid. Informationsbericht No. 86, 24. 4. 1937; cf. Weinberg, Starting World War II (see above, fn 52), pp. 145-46, 274.

112 Ibid. Informationsbericht No. 87, 5. 5. 1937; cf. Survey 1937, vol. I (see above, fn 64), p. 325. Neurath's account of his conversation with Mussolini on 3. 5. 1937 is ADAP, C VI 2, No. 350. There is no official record of Göring's conversation (ibid. p. 769, fn 2) but there are well-documented accounts of his policy towards Italy in Kube, Pour le mérite (see above, fn 4), pp. 224-32 and Martens, Hermann Göring (see above, fn 102), pp. 89-97, 102-103. Dertinger's informed guess about possible German intervention in Austria probably arose from German fears that the Austrian Government might restore the Habsburg dynasty to block an $A n s c h l u ß$ with Germany. Neurath warned Mussolini on 3.5. 1937 that Germany would not tolerate this (ADAP, C, VI2 [see above, fn 14], No. 350) and Blomberg ordered plans for military intervention to be prepared in case of a restoration (Müller, General Ludwig Beck [see above, fn 36], pp. 239-40). However, there is also a report in the Christie papers (see below p. 102 and fn 180) of a conversation between Beck and fellow officers in Paris in June 1937 in which Beck is alleged to have referred to a plan drawn up by Himmler in May 1937 with Hitler's approval to invade Austria with SS troops and it is possible that Dertinger had got wind of a rumour of this kind. Christie's informant was probably the German air attaché in Paris, Hans Ritter (Churchill College, Cambridge, Christie Papers, 1/21A); Nicholas Reynolds, Treason was no Crime. Ludwig Beck, Chief of the German General Staff(London, 1976), pp. 113-15.

113 Among his recent negative experiences with Britain were the British refusal to return a British or Dominions' mandate to Germany (which led to a French refusal), his conversation with Lord Lothian on 4. 5. 1937 of which Hitler gave a caustic account to the Hamburg Bürgermeister Carl Krogmann, the next day (Carl Vincent Krogmann, Es ging um Deutscblands Zukunft 1932-1939 [Leoni am Starnberger See, 1976], diary entry for 5. 5. 1937, p. 284; Weinberg, Starting World War II [see above, fn 52], pp. 98-99), the Blomberg-Eden conversation of 13.5.1937 which despite its cordial tone showed no willingness on Eden's side to make concessions (ADAP, C, VI 2 [see above, fn 14], No. 371, Enclosure 2 and DBFP, Second Series, XVIII [see above, fn 61], No. 495) and "The Times condemnation of the German bombing of Guernica (F. R. Gannon, The British Press and Germany 1936-1939 [Oxford, 1971], pp. 113-116) against which Hitler ordered press retaliation (ADAP, C, VI 2, No. 372; DBFP, Second Series, XVIII [see above, fn 61], No. 480). 
11 Ibid. 101/9: Anweisung No. 679, 27. 5. 1937, Ibid. 102/5: report of the press conference, from the files of another journalist, Fritz Sänger; cf. Fritz Sänger, Politik der Täuschungen. Mißbrauch der Presse im Dritten Reich (Vienna, 1975). The official was Werner Stephan of the Press department of the Propaganda Ministry (1895-1984), who gave a vivid account of the Ministry in Joseph Goebbels. Dämon einer Diktatur (Stuttgart, 1949).

116 Ibid. 101/30: Informationsbericht No. 92, 27. 5. 1937. The source was probably Otto Dietrich, Hitler's personal press representative. Hitler's remarks about the Imperial Conference are discussed in Appendix A, below pp. 108-109.

117 Cf. Survey 1937, vol. II (see above, fn 64), pp. 302-03.

119 Cf. Goebbels' reference, above p. 88

119 BA, ZSg. 101/30: Informationsbericht No. 96, 16. 6. 1937.

120 Ibid.: Informationsbericht No. 100, 26. 6. 1937.

121 Ibid. 101/9: Anweisung No. 821, 28.6. 1937 and Ibid. 101/10: Anweisung No. 887, 9. 7. 1937, Ibid. $101 / 31$ : Informationsbericht No. 118, 19. 8. 1937.

122 Ibid. 101/31: Informationsbericht No. 126, 30. 8. 1937. Cf. Survey 1937, vol. II (see above, fn 64), pp. 181-2, 339-52 and Stephen Roskill, Naval Policy between the Wars, vol. II: The Period of Reluctant Rearmament 1930-1939, (London, 1976), pp. 382-87.

${ }^{123}$ BA, ZSg. 101/31: Informationsbericht No. 126, 30.8. 1937 and No. 129, 1. 9. 1937. In fact the Auswärtiges Amt successfully resisted the pressure from Ribbentrop in favour of Japan until the end of October; Fox, Germany and the Far Eastem Crisis (see above, fn 71), Pp. 239-240 and ADAP, D I (see above, fn 14), No. 478.

124 ADAP, D I (see above, fn 14), Informationsbericht No. 140, 2. 10. 1937, discusses the Mussolini visit. Dertinger reported that Mussolini had agreed to a process of parallel development for Austria and Germany so that their policies would be synchronized on the model of Danzig, and in return he had been promised that there would be no $A n s c b l u \beta$. This is very close to Hassell's (German ambassador to Rome) account of Mussolini's position in Berlin; ADAP, C, VI 2 (see above, fn 14), No. 568. Cf. Goebbels' reference, above p. 90 . Hitler himself commented cryptically on 5 November according to Hoßbach's record: „Von der Seite Italiens sei[en] gegen die Beseitigung der Tschechei keine Einwendungen zu erwarten, wie dagegen seine Haltung in der österreichischen Frage zu bewerten sei, entziehe sich der heutigen Beurteilung und sei wesentlich davon abhängig, ob der Duce noch am Leben sei. « ADAP, D, I (see above, fn 14), No. 19, p. 30. These sources do not fully support Weinberg's conclusion that the German Government thought it had been given a free hand by Mussolini over Austria (Starting World War II [see above, fn 52], p. 282) although Göring, who in any case favoured a tough policy over Austria and who had broached the subject with Mussolini, behaved as though he had been given a free hand. Martens, Hermann Göring (see above, fn 102), pp. 115-16, Kube, Pour le mérite (see above, fn 4), pp. 236-43. For public consumption a photographic record of the Mussolini visit was issued with an introduction by Otto Dietrich in which he said that the unity of National Socialism and Fascism marked a turning point and that they would prevail over the opposition of all those who saw the old "Harmonie der Interessen the new force. Mussolini erlebt Deutschland. Ein Bildbuch von Heinrich Hoffmann mit einem Geleitwort von Dr. Otto Dietrich, Reichspressechef(München, 1937), p. 8.

125 BA, ZSg. 101/31: Informationsbericht No. 153, 2. 11. 1937, No. 155, 5. 11. 1937. On 5 November, according to Hoßbach's record, Hitler said that in the event of a war breaking out between Italy, Britain and France, Germany should supply Italy with raw materials. He did not have in mind "militärische Abmachungen mit Italien « but rather exploiting the situation to attack Czechoslovakia. ADAP, D, I (see above, fn 14), No. 19, p. 31.

126 Hauser, England und das Dritte Reich, 2 (see above, fn 60), pp. 188-91. The Manchester Guardian correspondent, F. A. Voigt, believed that "a high official« in the Foreign Office who was opposed to Halifax's visit, had been responsible. (Gannon, British Press and Germany [see above, fn 113], pp. 130-31.). Hitler was in any case an avid reader of the foreign press, hyper-sensitive to criticism and liable to assume that reports were officially inspired.

127 BA, ZSg. 101/31: Informationsbericht No. 163, 15. 11.1937, No. 165, 18. 11. 1937.

128 According to his evidence to allied interrogators in 1947, Dietrich's job from 1933 to September 1937 as Hitler's press aide was to orient Hitler on the world news. Every day Hitler read 100 pages of foreign news. Dietrich also communicated Hitler's views on what was to appear in the newspapers to the Propaganda Ministry, passing on Hitler's own words; IfZ, Munich, ZS 874: records of interrogations on 18.2., 1.5. and 7.10.1947. Dertinger confirmed that in the preparation of instructions to the press in the Propaganda Ministry, Dietrich brought forward Hitler's personal wishes and was therefore particularly influential; Ibid. ZS 870 Statement to an official of the U. S. War Crimes section of the War Department, 10.11.1947. See also the memoirs of the London representative of the official German press agency (Deutsches Nachrichtenbüro) Fritz Hesse, who records Dietrich as saying that Hitler took a special interest in the English press. Hesse also recalls that Ribbentrop's predecessor as German ambassador in London, Leopold von Hoesch, tried to prevent reports reaching Hitler which suggested that Britain thought war was inevitable. Fritz Hesse, Das Vorspiel zum Kriege. Englandberichte und Erlebnisse eines Tatzeugen 1935-1945 (Leoni am Starnberger See, 1979) pp. 10, 24. (This is a revised edition of a book originally published in 1953 under the title Das Spiel um Deutschland.) On Dietrich's position and his rivalry with Goebbels, 
Ernest K. Bramsted, Goebbels and National Socialist Propaganda 1925-1945 (Michigan, 1965), pp. $106-111$.

129 BA, ZSg. 101/31: Informationsbericht (from Kausch) No. 171, 25.11. 1937. A muted version of this briefing from the Auswärtiges $A m t$ is in ADAP, D, I (see above, fn 14), No. 40. Goebbels resented Dietrich's by-passing of the Propaganda Ministry and in his diary criticized Funk [head of the press department of the Propaganda Ministry] for not resisting him (entry for 25.11. 1937). In his Augsburg speech on 21 November Hitler said: "[. . . ] der Lebensraum unseres Volkes ist zu eng. Die Welt versucht, sich von der Prüfung dieser Probleme und Beantwortung dieser Fragen freizumachen. Aber es wird ihr nicht gelingen! Die Welt wird eines Tages unsere Forderungen berücksichtigen müssen.« Max Domarus, Hitler, Reden und Proklamationen 1932-1945. Bd I. Triumph. Zweiter Halbband 1935-1938 (Munich, 1965), p. 760. Further examples are Hitler's address to party officials in Sonthofen on 23 November (Ibid., pp. 761-63) and his speech to senior Generals on 22. 1. 1938 (BA-MA, RH 26-10, Bd. 255).

130 Ibid.: Informationsbericht No. 174, 2. 12. 1937; Hildebrand, Vom Reich zum Weltreich (see above, fn 103), pp. 540-41. Press speculation about colonial concessions to Germany at the expense of Portugal and Belgium arose from Schacht having put this idea to Halifax and a subsequent leak to the effect that it had been discussed with Halifax (Weinberg, Starting World War II (see above, fn 52), p. 121.) The British Government did in fact prepare an ambitious plan for a colonial settlement but in March 1938 Hitler made it clear that he was not interested (Ibid., pp. 131-40).

131 ADAP, D I (see above, fn 14), No. 19, p. 31. On the Italian presence in the Balearic Islands and the French reaction to a possible Italian attack on Minorca in October 1937, Survey 1937 (see above, fn 64), vol. II, p. 62-63 and Pp. 364-65. Hitler's views on Spain and a Mediterranean war are discussed in Appendix B below, p. 109.

132 Documents diplomatiques francais 1932-1938 (DDF), Deuxième Série, III, No. 213. DBFP, Second Series, XVII (see above, fn 61), Nos. 145, 210, 211, and XVIII, PP. VII-VIII. ADAP, C V (see above, fn 14), No. 574, VI 1, No. 99. Cf. Hjalmar Schacht, 76 Jabre meines Lebens (Bad Wörishofen, 1953) pp. 477-79, Michalka, Rippentrop (see above, fn 87), pp. 192-97.

133 DBFP, Second Series, XVIII (see above, fn 61), No. 148: Note by the Chief Economic Adviser to H. M. G., Sir F. Leith-Ross, 4. 2. 1937, enclosing a record of his conversation with Schacht on 2. 2. 1937, quotation on p. 194. On the conclusions the British drew from the Schacht-Leith-Ross contacts in 1937, C. A. MacDonald, "Economic Appeasement and the German >Moderates، 1937-1939. An Introductory Essay «, Past and Present, 56 (1972), pp. 106-11.

134 For example; Hitler to Halifax on 19 November 1937; ADAP, D, I, No. 33. Weinberg, Starting World War II (see above, fn 52), Pp. 69-70. The colonial issue is treated comprehensively in Hildebrand, Vom Reich zum Weltreich (see above, fn 103), pp. 491-548.

135 On British policy, DBFP, Second Series, XVIII (see above, fn 61), PP. VII-X from the preface by W. N. Medlicott and the documents cited there.

136 Weinberg, Starting World War II (see above, fn 52), p. 92.

137 Overy, Goering (see above, fn 102), p. 68; Kube, Pour le mérite (see above, fn 4), pp. 185-201; Martens, Hermann Göring (see above, fn 102), pp. 67-76. Goebbels' diary entries for 12. 8., 14. 8., 2-4. 11. 1937; BA ZSg 101/31; Dertinger's Privater Sonderbericht, 12. 7. 1937; Informationsbericht No. 132, 9. 9., No. 151, 28. 10., No. 152, 29. 10., and No. 154, 4. 11. 1937; Schacht, 76 Jabre meines Lebens (see above, fn 132), pp. 461-74.

138 See above, p. 90.

139 Foreign Relations of the United States (FRUS) (Washington, 1943-), 1937, vol. I, Pp. 169-70. DBFP, Second Series, XIX (see above, fn 61), No. 336, pp. 552-53.

140 ADAP, D, I (see above, fn 14), No. 19, pp. 27-28. Hildebrand suggests that Hitler's argument that Britain would not be willing to make colonial concessions may also have been intended to anticipate objections from his audience, Vom Reich zum Weltreich (see above, fn 103), p. 526. Hitler specified Angola as the only kind of "British " concession that was possible. This was closely parallelled by Schacht's suggestion to Halifax that Germany be given part of the Belgian Congo and of Angola (DBFP, Second Series, XIX [see above, fn 61], No. 336, p. 552). This similarity may reflect earlier discussions between Schacht and Hitler, though they drew opposite conclusions about the desirability of such colonial gains. Göring too suggested to Henderson that Portugal might be induced to sell or part with colonies to Germany (DBFP, Second Series, XIX [see above, fn 61], No. 238, p. 388). The idea was a natural one in view of the pre-1914 Anglo-German discussions of a partition of the Portuguese Empire (Weinberg, Starting World War II [see above, fn 52], p. 121).

141 DBFP, Second Series (see above, fn 61), XVIII, No. 527.

142 John L. Heinemann, Hitler's First Foreign Minister. Constantin Freiberr von Neurath, Diplomat and Statesman (Berkeley, London, 1979); Rainer A. Blasius, Für Großdeutscbland - gegen den großen Krieg. Ernst von Weizsäcker in den Krisen um die Tschechoslowakei und Polen (Cologne, Vienna, 1981), pp. 9-23. Weinberg, Starting World War II (see above, fn 52), p. 39. Michalka challenges the view that the aims of the Auswärtiges Amt towards Poland were no more than a revision of the Treaty of Versailles and the re-establishment of the frontier of 1914 on the strength of a memorandum, dated 13. 3. 1933, by the then Secretary of State Bernhard Wilhelm von Bülow which was used by Neurath for a major statement on foreign policy to the new Cabinet on 7. 4. 1933. Bülow wrote that the recovery of all Polish territory in question should be pursued simultaneously and par- 
tial or interim solutions should be refused, adding "nur noch eine Teilung Polens«. These words do not, however, require the interpretation which Michalka places on them. The word "Wiedergewinnung " most naturally refers to the frontier of 1914 rather than, as Michalka suggests, $1917-18$ and both the extent of the revision and the policy of simultaneous recovery of all the areas in question had been laid down by Stresemann in 1925-26. Bülow's memorandum does not therefore appear to mark a break with Stresemann's policy, as Michalka asserts. Wolfgang Michalka, "Conflicts within the German leadership on the Objectives and Tactics of German Foreign Policy, 1933-39《 in Wolfgang J. Mommsen, Lothar Kettenacker eds., The Fascist Challenge and the Policy of Appeasement (London, 1983), p. 51. Bülow's memorandum is printed in Hans-Adolf Jacobsen, Mißtrauische Nachbarn. Deutsche Ostpolitik 1919/1970. Dokumentation und Analyse (Düsseldorf, 1970), pp. 85-93, Neurath's statement in ADAP, C I (see above, fn 14), No. 142; cf. G. Wollstein, Vom Weimarer Revisionismus zu Hitler. Das Deutsche Reich und die Großmächte in der Anfangsphase der nationalsozialistischen Herrschaft in Deutscbland (Bonn, 1973), pp. 145-46 and on Stresemann, Christoph M. Kimmich, The Free City. Danzig and German Foreign Policy, 1919-1934, (New Haven and London, 1968), pp. 73-75 and ADAP, B, II 1 (see above, fn 14), No. 150.

143 Heinemann, Neurath (see above, fn 142), pp. 31-32, 90-96, Ciano's Diplomatic Papers (see above, fn 73), pp. 59-60, 116.

144 ADAP, C VI 2 (see above, fn 14), No. 312, 12. 4. 1937, cf. ibid. C VI 1, No. 216, 18. 2. 1937 and ibid., D, III, No. 157, 18. 12. 1936. Cf. Ulrich von Hassell, Vom anderen Deutschland. Aus den nachgelassenen Tagebüchem 1938- 1944 (Zürich, 1946), pp. 14-15.

145 DBFP, Second Series, XVIII (see above, fn 61), No. 545: report on a conversation with Burckhardt on 24. 5. 1937 by Mr. Edmond (Geneva), 27. 5. 1937. It is quite possible that Neurath knew that Burckhardt would report his conversation to British officials; in 1938 Weizsäcker, then State Secretary in the Auswärtiges Amt, used Burckhardt as a channel to the British Government; Blasius, Weizsäcker (see above, fn 142), p. 58.

146 The German documents are in ADAP, D, III (see above, fn 14), Chapter III: see particularly Nos. 270, 355; cf. DDF, Deuxième Série, VI (see above, fn 132), No. 18 and DBFP, Second Series, XVIII (see above, fn 61), Nos. 635, 644. Goebbels, who noted Hitler's comments on the failures of the military leaders in the two crises, added in an entry on the Leipzig incident (24.6.1937) that Neurath was also weak except when his attitude was stiffened by the Führer.

147 Weinberg, Starting World War II (see above, fn 52), p. 100 argues that Neurath tried to avoid accepting the British invitation. The documents, however, are consistent with the interpretation that Neurath wanted to go to London but had to proceed cautiously in view of Hitler's hostility. DBFP, Second Series, XVIII (see above, fn 61), Nos. 561, 563, 567, 571, 581, 582, 585, 596, 630, 633, 635; Henderson to Eden, 15.7. 1937, PRO: Ge 37/28, FO 954/10A; ADAP, D, III (see above, fn 14), Chapter III. Heinemann, Neurath (see above, fn 142), p. 157 argues that Neurath wanted to accept the invitation, a view which finds further support in the memoirs of Hitler's personal adjutant; Fritz Wiedemann, Der Mann der Feldherr werden wollte (Dortmund, 1964), pp. 156-7.

${ }_{148}$ DBFP, Second Series, XIX (see above, fn 61), Nos. 283, 294, 303, 307, 323. As with the June visit Neurath had to contend with Hitler's reluctance. When Neurath first heard of the suggestion on 2 November 1937 he commented wthat Herr Hitler had made so many advances to Great Britain without result that he might now see no reason to jump at a hand so reluctantly held out to him." (Ibid. No. 283). See also Henke, England in Hitler's politischem Kalkül (see above, fn 60), p. 112. Goebbels noted in his diary (24.11.1937) that Neurath shared his concern about the biased view of Britain which Hitler was getting from Ribbentrop and from Italy.

149 Fox, Germany and the Far Eastem Crisis (see above, fn 71), pp. 229-290.

150 ADAP, C VI 2 (see above, fn 14), No. 550, minute dated 13. 9. 1937. On Weizsäcker, see Leonidas E. Hill ed., Die Weizsäcker-Papiere 1933-1950 (Frankfurt, 1974); Blasius, Weizsäcker (see above, fn 142), and Michalka, Ribbentrop (see above, fn 87), pp. 197-204.

151 ADAP, D, I (see above, fn 14), No. 21, Memorandum dated 10. 11. 1937; cf. ADAP, D, III No. 317 and Hill, Weizsäcker-Papiere (see above, fn 150), pp. 118-19, 115-117. Weizsäcker's conclusion that time was not in Germany's favour marked a reversal of advice he had given on 18 November 1936 to the Reich Defence Committee that, »Wenn wir Frieden behalten, arbeitet die Zeit für uns« because Germany's new strength was bound to make allies of those states which had no snatürlichen Differenzen w with Germany (ibid.pp. 100-102). It is noticeable that he did not then rule out Germany taking the risk of war at a later date though in a private note in July 1936 he had argued that while Germany might exploit a conflict of third parties to regain Danzig, Memel and the Polish corridor, it should not itself launch a war for these goals (ibid., pp. 96-98).

152 Weinberg, Starting World War $I I$ (see above, fn 52), p. 118 argues that Weizsäcker had not grasped that the British condition for concessions would be a general settlement, but this seems improbable given his position. It is much more likely that he was well aware of the difficulty but hoped that in time Britain could be brought to accept limited German expansion East in return for security in the West.

153 ADAP, D, I (see above, fn 14), Nos. 22, 46, 50, 63. A convincing analysis of Britain's attitude is given by Michael Newman, »The origins of Munich: British Policy in Danubian Europe, 1933-1937 «, Historical Joumal, vol. 21 (1978), pp. 371-86. 
154 Weinberg, Starting World War II (see above, fn 52), p. 39; Blasius, Weizsäcker (see above, fn 142), pp. 36-37; ADAP, D I (see above, fn 14), No. 35 and Weizsäcker's marginal comment on No. 83.

155 ADAP, D I (see above, fn 14), No. 86. Neurath's reaction to the Halifax visit was similar. To Bullitt on 18 November he expressed scepticism saying that Halifax had brought no concrete proposals (FRUS, 1937, 1 [see above, fn 139], p. 168). In a circular to the principal embassies after the visit, on 22 November, he was cautiously optimistic (ADAP, D, I No. 33); but when Henderson asked him what Hitler expected as a result of the visit, he replied (truthfully) »not much “ adding (less frankiy) that while the Spanish Civil War continued it would be difficult to achieve agreement between the powers (DBFP, Second Series, XIX [see above, fn 61], No. 362: Henderson to Eden, 1. 12. 1937 recording his conversation with Neurath of 30.11 .1937$)$.

156 Hesse, Das Vorspiel zum Kriege (see above, fn 128), pp. 48-51.

157 IMT, XIV (see above, fn 1), p. 36. Göring's argument that Neurath had been included in order to make it clear to Fritsch that the international situation required forcing the speed of rearmament (IMT, IX, p. 307) is hardly convincing since Neurath was unlikely to support this view, and indeed did not.

158 Fox, Germany and the Far Eastem Crisis (see above, fn 71), pp. 251-67, Theo Sommer, Deutschland und Japan zwischen den Mächten 1935-1940 (Tübingen, 1962), pp. 82-93. ADAP, D, I (see above, fn 14), No. 488; Erich Kordt, Nicbt aus den Akten (Stuttgart, 1950), pp. 168-73; DBFP, Second Series, XIX (see above, fn 61), Nos. 283, 294.

159 It is interesting that one of Christie's informants, Hans Ritter (see above, fn 112) took the view that Hitler's support for Italy was bluff to secure a settlement with Britain (Christie's notes, dated 19 September and November 1937, Christie Papers, 1/21A) although by December 1937 Christie's information was that Hitler was leaning towards the "Radicals«, who »want to go the whole hog with Italy and Japan«. The $»$ Radicals « Christie identified as Himmler, Goebbels (inaccurately), Rosenberg and Ribbentrop. The alternative »Conservative policy " he identified with Neurath, Blomberg and Göring, "who still appear to favour trying to reach or force a working understanding with G[reat] Britain «. (»A few rough notes of impressions gathered in Germany in Dec. 1937 «, dated 14 January 1938, Christie Papers 1/21B). For an assessment of Rosenberg's and Himmler's limited influence on foreign policy up to 1938, see Hans-Adolf Jacobsen, Nationalsozialistische Außenpolitik 1933-1938 (Frankfurt, 1968), pp. 45-89, 461-66.

160 See below, p. 100.

161 IMT, XVI (see above, fn 1), 640-41. In view of Neurath's testimony at Nuremberg that he was "extremely upset at Hitler's speech " 5 November (Ibid., p. 640) it is surprising that Bullitt found him "supremely self-confident " and "cocky» in their conversation on 18 November (FRUS, 1937, 1 , p. 167). However, this might be explained by Ribbentrop being temporarily out of favour with Hitler (See below p. 104). Neurath had succeeded in excluding Ribbentrop from the Halifax visit (DBFP, Second Series, XIX [see above, fn 61], Nos. 327, 328; ADAP, D I [see above, fn 14], Nos. 24, 32) and on 16 November Neurath told Henderson that he would not be surprised if the British Government were to declare Ribbentrop »no longer a persona grata (DBFP, Second Series, XIX [see above, fn 61], No. 332). Neurath may also have been encouraged by the support he received from Fritsch and Beck.

162 ADAP, D, I, No. 19 (see above, fn 14), p. 32.

163 IfZ, ED 91 (Nachlaß Geyr von Schweppenburg), vol. 5: draft report to the Reich War Ministry, dated 15. 10.1936; vol. 6: draft report dated 19.2.1937.

164 Ibid.vol. 6, cf. Geyr, Erinnerungen (see above, fn 95), pp. 164-72. In his reports Geyr emphasized the importance of air power and of political and economic factors, particularly Britain's relations with the United States. He told Ulrich von Hassell in November 1939 that he had been attacked by the party during his time as military attaché in London, because he took the view that Britain was not bluffing; only Fritsch and Beck had believed him. Hassell, Vom anderen Deutschland (see above, fn 144), p. 103.

165 DBFP, Second Series, XVIII (see above, fn 61), No. 495. Blomberg had been chosen in preference to Göring (Ibid. No. 232). Hoßbach claimed that this was his idea (BA-MA, N 24/128). Göring's injured pride may have been one factor in his intrigue against Blomberg and the army command. Hoßbach, Zwischen Webrmacht und Hitler (see above, fn 33), p. 31.

166 DDF, Deuxième Série, VI (see above, fn 132), No. 18; DBFP, Second Series, XVIII (see above, fn 61), No. 635.

167 DBFP, Second Series, XIX (see above, fn 61), No. 336, pp. 552, 554-5, and No. 362. Hitler encouraged the view of himself as the rejected suitor. In an outburst to the League High Commissioner for Danzig, Burckhardt, which was probably deliberate since he knew that Burckhardt reported to Eden as President of the League Council Committee for Danzig, on 20 September 1937, Hitler claimed to have loved Britain all his life, to have offered German friendship unceasingly and to have been rejected. This, he said, was pure madness from which the greatest catastrophes could result but he had to accept it. He continued to speak of Germany's strength, its need to expand and its powerful allies (Japan and Italy) and friends (Austria). Carl J. Burckhardt, Meine Danziger Mission 1937-1939 (Munich, 1960), pp. 99-100.

169 Beck is reported to have made an interesting comment in this connexion in a conversation with fellow officers in Paris in June 1937. According to Christie's record, which was probably based on in- 
formation from Hans Ritter (see above, fn 112), Beck said "In a recent talk with me Blomberg spoke of the likelihood of war between Russia and Germany. I said I could see no grounds whatever for such a war. He replied , War against USSR seems to be unavoidable because Communism and Nat[iona]l Socialism can never both exist alongside each other.< I asked him >Has mankind really gone back to the Religious Wars of the Middle Ages? Blomberg answered >Doch, so ähnlich denke ich mir den Verlauf der zukünfrigen Politike. (Christie Papers, 1/21A).

169 This famous memorandum is printed in Müller, General Ludwig Beck (see above, fn 36), pp. 498-501, and discussed on pp. 254-56, 260-62. See also Reynolds, Treason was no Crime (see above, fn 112), pp. 117-120. Geyr records that Beck was receptive to his warnings and conscientiously read The Times; Geyr, Erinnerungen (see above, fn 95), Pp. 46, 48, 88-89, 171. Helmut Krausnick argues convincingly that Beck's opposition was not based simply on strategic considerations, »Zum militärischen Widerstand gegen Hicler 1933-1938. Möglichkeiten, Ansätze, Grenzen und Kontroversen « in Vorträge zur Militärgeschichte, ed. Militärgeschichtliches Forschungsamt, Bd 5, Der militärische Widerstand gegen Hitler und das NS-Regime 1933-1945 (Herford, Bonn, 1984), pp. $27-80$.

170 IMT, XIV (see above, fn 1), pp. 35, 37.

171 Dülffer, Weimar, Hitler und die Marine (see above, fn 4), pp. 451-53.

172 Wilhelm Deist, The Webrmacht and German Rearmament (London, 1981), p. 78. It is interesting that Beck is reported to have said that neither Raeder nor Göring would observe any international agreement on arms limitation, in a conversation with fellow officers in Paris in June 1937 (Christie Papers, 1/21A); Reynolds, Treason was no Crime (see above, fn 112), p. 113.

173 Alfred Kube gives a penetrating analysis of Göring's ideas in Pour le mérite (see above, fn 4), summarized on Pp. 203-215. R. J. Overy argues conversely that Göring's foreign policy like Hitler's was ma direct product of Nazi ideology", that his aim was to transform Europe and Asia in Germany's favour and that he saw Germany's chief enemies as the Soviet Union and the British Empire (Goering [see above, fn 102], pp. 76-78). Dr Overy refers to Göring's conversations with Group Captain Christie in 1937 in support of this interpretation, saying Göring hoped that "Britain might offer Germany a free hand in the east to solve the Russian question and find sliving spacec. Soviet Russia was to be overturned.« (Ibid., p. 77). However, this is at variance with Christie's record of the conversations, which consistently refers to Eastern and South Eastern Europe not the Soviet Union as the goals of German expansion. (Christie Papers, 1/5, 1/21A).

174 Kube, Pour le mérite (see above, fn 4), pp. 265-323.

175 Kube, Pour le mérite (see above, fn 4), pp. 151-264. There is also an excellent, detailed account of Göring's diplomacy towards Britain in Martens, Göring (see above, fn 102), pp. 77-128.

176 ADAP, D, I (see above, fn 14), No. 19, p. 32. Edward L. Homze, Arming the Luftwaffe. The Reich Air Ministry and the German Aircraft Industry 1919-39 (Lincoln (Nebraska) and London, 1976), pp. 170-171. According to the Hoßbach record, Hitler agreed to Göring's suggestion but reserved the question of timing for later decision. In fact German forces were not withdrawn because of Spanish pressure and from concern at the anticipated Italian reaction, but Hitler would have liked to have withdrawn them in April 1938 when for a short time Franco thought he had no further need of them. Abendroth, Hitler in der spanischen Arena (see above, Appendix B), pp. 209-210; ADAP, D III (see above, fn 14), No. 559.

177 Conversation with Halifax, 20.11. 1937 (DBFP, Second Series, XIX (see above, fn 61), No. 336, p. 551).

178 Conversation with Henderson, 11. 9. 1937 (Ibid., No. 160, Annex IV, p. 288). This curious idea originated with Hitler. Ribbentrop, Zwischen London und Moskau (see above, fn 83), p. 67; Kuhn, Hitlers außenpolitisches Programm (see above, fn 60), pp. 194-6; Winston S. Churchill, The Second World War, vol. 1., (London, 1948), pp. 200-201.

179 Conversation with Henderson, 24. 5. 1937 (DBFP, Second Series, XVIII [see above, fn 61], No. 538), with Christie 28. 7. 1937 and September 1937. The July conversation is recorded in the book based on Christie's papers, T. P. Conwell Evans, None So Blind (privately printed, London, 1947 and circulated only after Christie's death in 1972), pp. 81-88. The original record is in Christie Papers, 1/5. There is no reference to the September 1937 conversation in None So Blind but Christie's record of it, dated 19 September 1937, is also in 1/5. According to a separate note entitled „Germany September 1937 “, the conversation took place during the Nuremberg rally, which lasted from 8-13 September (Ibid. 1/21A). Göring consistently expected Italy to subordinate its ambitions in South East Europe and the Balkans to Germany. Kube, Pour le mérite (see above, fn 4), pp. 83, 90, 100-101, 129-30, 174-75, 214, 216-49.

180 Conversations with Henderson, 20.7.1937 and 11. 9.1937 (DBFP, Second Series, XIX [see above, fn 61], Nos. 52 and 160 Annex IV). Conversations with Christie, 3. 2. and 28.7. 1937 (None So Blind [see above, fn 179], pp. 76-77, 85-87) and September 1937 (Christie Papers, 1/5). For Göring's policy in South East Europe, see Kube, Pour le mérite (see above, fn 4), pp. 74-103, 129-38, 179-85, 214-49. Christie had been British Air Attaché in Berlin from 1927 to 1930, when he retired from the R. A. F. and went into business. On close terms with Göring, Milch and other figures in official circles in Berlin, he was in a position to gain unique insights into German policy through his frank and unofficial discussions with them, and the content of these discussions he reported in great detail to his friend the Permanent Under-Secretary at the Foreign Office, Sir Robert 
Vansittart. Whether Christie's German contacts realized this is uncertain but it is unlikely they thought Christie was gathering information simply for himself. Walter Schellenberg, who worked for Heydrich in the SS security service, assumed incorrectly that Christie was a member of the British secret service; Walter Schellenberg, Memoiren (Cologne, 1956), p. 57; F. H. Hinsley, British Intelligence in the Second World War. Its influence on strategy and operations, vol. 1. (London, 1979), p. 47; Wesley K. Wark, The Ultimate enemy. British Intelligence and Nazi Germany 1933-1939 (London, 1986), pp. 52-55.

181 Christie's report of the conversation on 3. 2. 1937 (None So Blind [see above, fn 179], pp. 78-80).

182 Irving, Milch (see above, fn 4), pp. 54-57. Milch also reported at the end of October and the beginning of November to Neurath, Blomberg, Göring and to Hitler himself (on 2 November) on a visit to Britain where he had been impressed by the system of "shadow" factories which could be converted wholly to arms production. To the Italian ambassador in Berlin, Attolico, he said that at its present rate Britain would be "pronta in the air in two years. (Attolico's report of 26 October 1937 to the Italian Ministry of Foreign Affairs; Archivo Storico, Ministero degli Affari Esteri, Rome; Serie Affari Politici, Germania, 1937, Busta N. 41, Fasc. 3.) If he also said this to Hitler it would have strengthened Hitler's desire for early action against Czechoslovakia, just as it would have increased the fears of Blomberg (whom Milch found very depressed) and Neurath. Milch's account of Hitler's views at this time is itself of some interest. While in Britain, he told Christie that Hitler had told him before he left, "We must stick to it and get an alliance with Great Britain, we cannot stake all on Italy which has au fond so little to offer us: but we must not throw away the Italian card. Mussolini is belpful to us and we must make use of bis friendly efforts, but not encourage him too far." (Rough Notes of Conversation with General Milch, 21 October 1937, Christie Papers 1/21A). These sentiments sound suspiciously like those of Göring or Neurath rather than Hitler, and of course they were intended to reassure Milch's British hosts. Milch also alleged in his post-war memoirs that when he reported back after the visit, Hitler stressed that he was interested only in collaboration with Great Britain and the Empire. Milch's diary entry for 2 November reads simply. »15,15 17,15 mit Udet lange Führer betr[effend] Reise England (große Politik) [. . . ] . Below, the Luftwaffe adjutant, who was also present, agrees in his memoirs that Hitler emphasized that he did not want war with Britain. If Milch's account of the tone of the conversation is accurate, it was in marked contrast to the views Hitler expressed on 5 November. Either Milch mis-reported the interview, or Hitler simply told him what he wanted to hear and what was in any case Hitler's general line of reassurance to the armed services that there would be no war with Britain. Milch diaries, also postwar, edited transcripts of his diaries, and manuscript of his memoirs (microfilm copies in the Imperial War Museum, London); Below, Als Hitlers Adjutant (see above, fn 36), p. 48; Irving, Milch (see above, fn 4), pp. 58-60; Martens, Göring (see above, fn 102), p. 118.

183 Christie Papers $1 / 5$ and „Germany: September 1937 « ibid., 1/21A.

${ }_{184}$ DBFP, Second Series, XVIII (see above, fn 61), Nos. 538, 574 and XIX, No. 41 ; Ibid., XIX, Nos 52, 160 Annex IV, No. 238 Enclosure.

185 Ibid. No. 272 and No. 504, p. 875. Henderson to Halifax, 4. 11. 1937 (PRO: FO 800/268); Henderson to Foreign Office, 9. 11. 1937, in which he commented that Mackensen, the State Secretary in the Auswärtiges Amt, had been pleased to hear that Göring was in favour of the visit as (Mackensen explained) "Hitler was surrounded by other influences who recommended other courses (Rome axis, Japan etc.).« (DBFP, Second Series, XIX [see above, fn 61], No. 303); Henderson to Eden, 9. 11. 1937 (Avon Papers, Ge 37/40, FO 954/10A.)

186 DBFP, Second Series, XIX (see above, fn 61), Nos. 298 and 332.

187 Ibid., No. 336, p. 545, and Martens, Göring (see above, fn 102), pp. 120-22.

188 Martens, Göring (see above, fn 102), pp. 126-28.

189 Below, Als Hitlers Adjutant (see above, fn 36), p. 67.

190 Ribbentrop, Zwischen London und Moskau (see above, fn 83), p. 93. Michalka, Ribbentrop (see above, fn 87), especially pp. 154-71.

191 ADAP, C, VI 2 (see above, fn 14), No. 380. Hitler on 5 November argued the reverse - that the emphasis put on the Crown was a sign of the weakness of the Empire (see above pp. 85-86; Michalka, Ribbentrop [see above, fn 87], p. 167).

192 Weizsäcker and Neurath were unhappy about the proposed tactics. Weizsäcker commented in the margin, "Ich bin mehr für schrittweise Bekehrung als für ein baldiges jüngstes Gericht.« and Neurath underlined and queried the word "kompromißlos«; ADAP, C, VI 2 (see above, fn 14), No. 380 , p. 825 .

193 Churchill, The Second World War, vol. 1 (see above, fn 178), pp. 200-201. Cf. Hesse, Das Vorspiel zum Kriege (see above, fn 128), pp. 72-74.

194 Kordt, Nicht aus den Akten (see above, fn 158), pp. 168-78; cf. Jacobsen, Nationalsozialistische Außenpolitik (see above, fn 159), p. 313. Kordt adds that when he returned to Berlin in February, he was told by Rudolf Likus (an old friend and assistant of Ribbentrop's) that Ribbentrop had waited in vain for the whole of January to be received by Hitler and that the invitation to become Foreign Minister on 2 February came without warning. This suggests that Hitler had not planned to make the change, at least so soon, and that the immediate cause was the Blomberg-Fritsch crisis. This finds support in the Goebbels diary entry for 1. 2. 1938, which describes the change of Foreign Min- 
ister as a way of covering up the Blomberg-Fritsch crisis by making it part of a wider change of Government.

195 The only surviving copy of this document is in the Foreign and Commonwealth Office, Library and Records Department, London; F1/GB. 3 (unfilmed), von Loesch Collection. It was found by David Irving, having been overlooked by the editors of ADAP, and was published (with minor transcription errors) in Anneliese von Ribbentrop, Die Kriegsschuld des Widerstandes (Leoni am Starnberger See, 2nd. edn., 1975), pp. 61-75.

196 Ribbentrop clearly here reflected the views of Geyr von Schweppenburg whose final report of 20.9. 1937 he had read and criticized as "zu pessimistisch". Geyr, Erinnerungen (see above, fn 95), pp. 169-70 and Geyr's report of his conversation with Ribbentrop, dated 5. 10. 1937, to Oberkommando des Heeres, copy in IfZ, ED 91, vol. 6; also Michalka, Ribbentrop (see above, fn 87), pp. 162-63.

197 Cf. the following extract from Thomas Jones to Lady Grigg, 24. 10. 1937, recording a conversation with Eden: "[...] Eden himself thinks the Cabinet very weak and the armament programme far in arrears. On the other hand, he seems to argue that we can't do business with Germany until we are armed - say in 1940 [...]« Thomas Jones, A Diary with Letters 1931-1950 (London, 1954), p. 370.

199 ADAP, D I (see above, fn 14), No. 93.

199 Ribbentrop was in Berlin at the beginning and end of June; he was at the Nuremberg rally from 8-13 September and in Germany again for the Mussolini visit from 25-28 September. He returned to Berlin at the beginning of October and again on the 17 th before going on to Rome, arriving back in Berlin on the 24th. Michalka, Ribbentrop (see above, fn 87), pp. 157-58. Cf. Ribbentrop, Zwischen London und Moskau (see above, fn 83), pp. 74-76 where Ribbentrop describes his efforts to persuade Hitler that British opposition was a political reality and that Britain would fight to preserve its concept of the balance of power in Europe. Naturally, he blamed this British opposition for forcing Germany to build up the Anti-Comintern Pact, ibid., p. 113.

200 ADAP, D, I (see above, fn 14), p. 25. Hoßbach records that Hitler spoke from notes; Hoßbach, Zwischen Webrmacht und Hitler (see above, fn 33), p. 219. Neurath said at Nuremberg that Hitler's speech lasted $» 2$ or 3 hours«; IMT, XVI (see above, fn 1), pp. 639-40.

201 Goebbels' record of Hitler's shock and sorrow at losing Blomberg is perfectly plausible; diary entries for 26. 1.-1. 2. 1938.

202 Henke, England in Hitlers politischem Kalkül (see above, fn 60), pp. 152-62; Deist, Webrmacht and German Rearmament (see above, fn 172), Pp. 66-69, 78-85. 


\section{Veröffentlichungen des Militärgeschichtlichen Forschungsamtes:}

Soeben erschienen:

Hans-Joachim Harder: Militärgeschichtliches Handbuch Baden-Württemberg. Hrsg. vom Militärgeschichtlichen Forschungsamt. Kohlhammer-Verlag Stuttgart 1987. 387 S. $59,-\mathrm{DM}$

Günther Hebert: Das Alpenkorps. Aufstellung, Organisation und Einsatz einer Gebirgstruppe im Ersten Weltkrieg. Harald Boldt Verlag Boppard a. Rh. 1988 (= Militärgeschichtliche Studien. Bd 33.) 176 S. 40,-DM

In Vorbereitung:

Anfänge westdeutscher Sicherbeitspolitik 1945-1956. Hrsg. vom Militärgeschichtlichen Forschungsamt. Bd 2: Lutz Köllner, Klaus A. Maier, Wilhelm Meier-Dörnberg, HansErich Volkmann: Die EVG-Phase. Verlag Oldenbourg München

Krieg, Wirtschaft und Gesellschaft in Europa im Zeitalter Friedrich des Großen. Im Auftrag des Militärgeschichtlichen Forschungsamtes hrsg. von B. R. Kroener. Mit Beiträgen von H. Bleckwenn, K.-R. Böhme, T. Hayter, J. Keep, B. R. Kroener, J. Kunisch, M. Messerschmidt, H. Neuhaus, W. Petter, A. Simsch, R. Vierhaus. Verlag Oldenbourg München

Martin van Creveld: Kampfkraft. Militärische Organisation und militärische Leistung 1939-1945 (= Einzelschriften zur militärischen Geschichte des Zweiten Weltkrieges. Bd 31.) Verlag Rombach Freiburg.

Operatives Denken und Handeln in deutschen Streitkräften im 19. und 20. Jabrbundert. Mit Beiträgen von H. Boog, L. Burchardt, K.-H. Frieser, Chr. Greiner, C.-G. v. Ilsemann, J.-A. Graf v. Kielmansegg, H. Magenheimer, W. Meier-Dörnberg, K.-V. Neugebauer, M. Salewski ( = Vorträge zur Militär- und Kriegsgeschichte. Hrsg. vom Militärgeschichtlichen Forschungsamt. Bd 9.) Verlag E. S. Mittler \& Sohn Herford, Bonn 